\title{
西太平洋板片俯冲与后撤引起华北东部地幔置换 并导致陆内盆-山耦合
}

\author{
郑建平*，戴宏坤 \\ 中国地质大学(武汉)地球科学学院, 地质过程与矿产资源国家重点实验室, 武汉 430074 \\ *E-mail: jpzheng@cug.edu.cn
}

收稿日期: 2017-07-01; 收修改稿日期: 2017-12-19; 接受日期: 2018-01-08; 网络版发表日期: 2018-03-08

深地资源勘查开采重点专项项目(编号: 2016YFC0600403)和国家自然科学基金项目(批准号: 91214204)资助

摘要 华北中生代构造-岩浆活动频繁, 深部岩石圈地幔性质发生变化, 即克拉通发生活化作用. 活化作用大致可 分为三个阶段: (1) 晚古生代至早侏罗世(至 170Ma), (2) 中侏罗世至早白严世早期(160 140Ma), (3) 早白严世至 新生代( 140Ma以来). 其中后两个阶段与古太平洋板片俯冲及后撤导致华北东部深部的岩石圈地幔置换并引起 陆内浅部的盆山耦合过程是本文讨论的重点。在第一阶段，古亚洲洋俯冲和关闭引起华北北缘经历弧后拉张、碰 撞挤压及碰撞后伸展等构造-岩浆活动, 而且造成陆块边缘完整性的机械破坏和地幔性质的化学改造, 成为后续 软流圈物质上涌的通道和岩浆活动的优先发生区; 受华南陆块俯冲的影响, 华北南缘也发生了类似的过程. 在第 二阶段, 蒙古鄂霍次克洋闭合及古太平洋板片俯冲剪切, 引起华北北缘的两次近S-N向的挤压作用(燕山运动的 $\mathrm{A} 、 \mathrm{~B}$ 幕), 近E-W 向分布的陆缘盆地被晚中生代岩体和NE-SW断裂肢解为零星分布的盆岭省, 岩浆作用由东北角 向西迁移进入地块内部，同时邩庐断裂的性质由左行走滑转换为正断层，华北由早期的近 S-N向的压扭性背景进 入NW-SE向的弧后拉张阶段. 第三阶段是华北克拉通破坏和岩石圈地幔增生的关键时期, 深部难熔的克拉通型地 幔被饱满的大洋型地幔置换, 实现岩石圈大幅度减薄后的小幅增生增厚过程; 浅部的表现是岩浆作用持续向东南 迁移，陆内岩石圈薄弱带优先发生伸展变形，包括在早白严世(140 110Ma)中部带侏罗纪逆冲断层反转为正断 层、郯庐断裂的持续拉张引起中地壳拆离和大渤海湾盆地的沉降; 晚白严世至今 (110Ma ), 中部山带发生断陷 作用形成汾渭盆地和沁水盆地，大渤海盆地内部断陷形成盆一山相间的地貌特征，苏鲁造山带则发育莱阳盆地等. 华北克拉通规模小并发育陆内薄弱带, 是克拉通容易破坏的内因. 具这种特性的克拉通容易受周边多个俯冲构造 域和上涌软流圈物质的共同影响. 晚中生代( 160Ma) 以来, 华北克拉通破坏主要表现为周边块体的俯冲导致软流 圈物质上涌、岩石圈减薄和浅部地壳滑脱, 岩石圈薄弱带处(如中部山带)出现褶皱和逆冲, 实现伸展背景下的局 部挤压; 俯冲板块后撤( 140Ma)则使上涌的软流圈回落形成岩石圈并实现地幔小幅增生置换 $(\sim 125 \mathrm{Ma})$ 与伸展背 景下浅部地壳断陷和成盆过程. 因此, 西太平洋板片俯冲和后撤是引起华北东部深部岩石圈地幔置换并导致陆内 浅部盆一山耦合的外在动力来源, 表明华北克拉通破坏是地块内部与地块边缘、深部过程与浅部盆一山耦合响应的 综合地质记录, 我们认为这也是燕山运动的本质.

\footnotetext{
中文引用格式: 郑建平, 戴宏坤. 2018. 西太平洋板片俯冲与后撤引起华北东部地幔置换并导致陆内盆-山耦合. 中国科学：地球科学, 48: 436-456, doi: $10.1360 / \mathrm{N} 072017-00222$

英文引用格式: Zheng J P, Dai H K. 2018. Subduction and retreating of the western Pacific plate resulted in lithospheric mantle replacement and coupled basinmountain respond in the North China Craton. Science China Earth Sciences, 61: 406-424, https://doi.org/10.1007/s11430-017-9166-8
} 
关键词古太平洋板片, 俯冲与后撤, 地幔置换, 盆一山耦合, 华北克拉通破坏, 深部过程与浅部响应, 燕山运动

\section{1 引言}

克拉通因具有低地温、低密度、巨厚刚性岩石圈 的特性，通常可稳定存在数十亿年(Griffin等，1999, 2003; Lee, 2006; Lee等, 2011). 然而, 也有克拉通出现 了明显的活化作用(例如，陈国达，1956; Zheng等， 2004b, 2015; Hughes等, 2014; Kusky等, 2014; Dave和 Li, 2016). 控制克拉通稳定性的因素, 如克拉通活化的 机制和动力学背景等, 已成为地球科学研究中的热点 (如吴福元等, 2008; Lee等, 2011; Zheng等, 2015). 作 为克拉通之一的华北，最古老岩石的形成年龄可追溯 到古太古代(Liu等，1992；Zheng等，2004a)，在太古代 末期由多个微陆块拼合而完成克拉通化过程(翟明国, 2008，2011；Zhai和Santosh，2011)，或在古元古代由 东、西陆块沿中部山带拼合后保持长期稳定(Zhao等, 2005). 在中生代，华北浅表地壳发生强烈变形(Davis 等, 2001; 徐刚等, 2006; Wang等, 2011)、广泛的岩浆 活动(Zhang等, 2014)、区域成矿作用(毛景文等, 2005; Sun等, 2007; Li L等, 2015; Wang C M等, 2015)、大型 沉积盆地形成(李忠等, 2003; 刘少峰等, 2004a; 王永超 等, 2016), 陆下岩石圈地幔性质变化等(Zheng等, 1998; 郑建平，1999)，这些都表明华北克拉通发生了活化与 破坏. 前人对华北克拉通活化破坏的机制, 时空范围和 动力学背景等曾有讨论, 并取得丰硕成果(郑建平, 1999; Xu，2001; Zhang等，2002，2008; 吴福元等, 2008; 朱日祥和郑天愉, 2009; Windley等, 2010; 朱日 祥等, 2011), 但对所发生的深部与浅部、板内与板缘 等复杂过程是如何协同运行的, 却鲜有涉及. 本文针对 这些问题进行讨论，结果对认识华北克拉通的减薄和 破坏, 包括燕山运动本质, 具有重要意义.

\section{2 华北地块周边的俯冲/碰撞作用}

华北克拉通规模较小，周围被多个构造域或造山 带包绕(图1a). 在北侧, 华北与西伯利亚地块之间经过 一系列的俯冲碰撞事件后形成了中亚造山带(Xiao等,
2015), 包括古亚洲洋向南俯冲并于二叠纪沿索伦缝合 带闭合(Windley等，2007)形成统一的蒙古-华北地块, 以及鄂霍次克洋于侏罗纪沿蒙古-鄂霍次克缝合带自 西向东呈“剪刀口式”闭合(Yin和Nie，1996; Yang等, 1998; Kravchinsky等, 2002; Tomurtogoo等, 2005)等复 杂过程; 在南侧, 大别-苏鲁造山带和秦岭-桐柏-红安造 山带, 通常被认为是华南陆块与华北陆块及中间可能 存在的微陆块在寒武纪到三叠纪时期多阶段复杂拼合 的结果(Wu和Zheng, 2013), 就俯冲极性来说, 一般认 为是华南板块俯冲至华北之下(例如, Li等, 1993, 2000; Zheng等, 2005; Wu等, 2009; Dong和Santosh, 2016), 但 是也有人提出可能存在局部的华北向华南板块俯冲 (例如, Li等, 2017a). 主要拼合阶段包括: (1) 古生代早 期秦岭与华北地块沿商丹缝合带拼合( Gao等, 1995; Dong等, 2011; Li Y等, 2015), (2) 晚志留-早泥盆世古 特提斯洋打开(Meng和Zhang, 2000; Wu等, 2009)以及 (3) 三叠纪华南与华北地块最终碰撞拼合等过程( $\mathrm{Li}$ 等, 2000; Zheng等, 2003; Zheng等, 2014; 郑永飞, 2008; Wu 等，2009). Li等(2017b)对秦岭造山带及其西部延伸给 出了细致的构造划分.

在华北克拉通东部, 侏罗纪以后, 主要是古太平洋 板片(伊泽奈崎板片)俯冲至东亚大陆之下(Maruyama 等, 1997; Sun等, 2007, 2015; Chough和Sohn, 2010; Safonova和Santosh, 2014), 并可能因板片运动方向发 生了多次变化(Northrup等, 1995; Sun等, 2007), 导致华 北的构造应力场由压扭性向弧后拉张转变( $\mathrm{Zhu}$ 等, 2005, 2010; 张岳桥和董树文, 2008; 徐佑德, 2009). 现 今华北东部通常被认为是一个“大地幔楔”(图2, Zhao 等, 2009; Kusky等, 2014), 其下有可能来自太平洋俯 冲的滞留板片(Fukao等, 2009; Zhao等, 2009; Kuritani 等, 2011; Tang等, 2014). 但是, 东亚大陆边缘之下在早 白严世是否存在“大地幔楔”还缺乏证据. 太平洋板片 俯冲而构成的“大地幔楔”是在近 $30 \mathrm{Ma}$ 时形成的，晚中 生代的“大地幔楔”结构是否可以由古太平洋板块(伊 泽奈崎板片)俯冲造成还只是推测(Liu等, 2017), 也许 俯冲消减的古太平洋板片已经沉入下地幔(Seton等, 2015). 


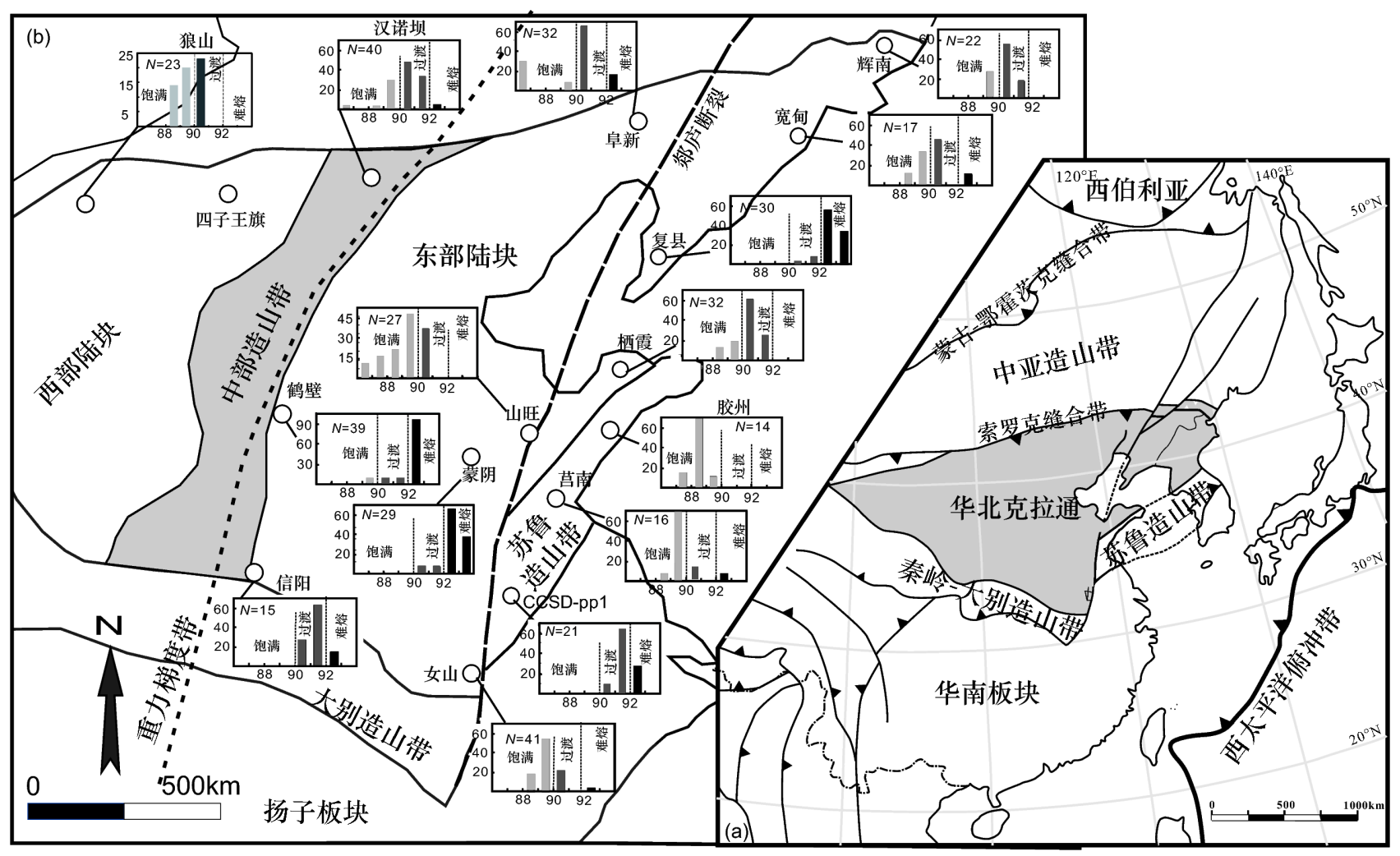

图 1 华北克拉通构造位置(a)以及地幔捕虏体橄榄石 $\mathrm{Mg}^{\#}$ 特征分布图(b)

(a) 改自Li等(2016); (b) 改自Zheng等(2007), (b)中除狼山是作者待发表数据外, 其他地区的数据来自Zheng等(2007)及其中的文献

\section{3 岩石圈减薄与地幔增生置换}

岩石圈地幔的厚度和组成等通常会对克拉通的稳 定性及地表的构造-岩浆-盆地演化有深刻影响。相对 于二辉橄榄岩, 方辉橄榄岩通常被认为是高度熔体抽 取后的残余体，具有较低的密度、较高的熔点和粘度, 可以稳定地漂浮在软流圈之上(Griffin等，1999; Lee, 2006; Pearson和Wittig, 2008). 此外，巨厚的岩石圈通 常可以抑制软流圈诱发的部分熔融，使其难以受到足 够的熔体富集作用而保持长期稳定 (Lee 等，2011; Zheng等，2015). 古老克拉通通常有岩石圈厚度大、 地温低的特点, 地幔主体由难熔的方辉橄榄岩组成; 显生宙岩石圈则不同，它们的厚度薄、地温高，主体 由饱满的二辉橄榄岩组成(Carlson等，1999，2005; 郑 建平, 1999).

华北有不同时代的火山岩，它们中的橄榄岩包体 为研究岩石圈地幔演化提供了绝佳窗口(图1b). 古生 代金伯利岩中的地幔包体多见石榴石方辉橄榄岩，并
有金刚石，指示当时的岩石圈厚度大(Griffin等，1999; 郑建平等，1999); 新生代玄武岩中者多为尖晶石二辉 橄榄岩，显示岩石圈厚度薄(Xu等，2003; Zheng等， 2007; Sun等，2012; Zou等，2016). 橄榄石的 $\mathrm{Mg}^{\#}$ 值、 斜方辉石的 $\mathrm{Mg}^{\#}$ 和 $\mathrm{Cr}^{\#}$ 值, 以及辉石的 $\mathrm{Al}_{2} \mathrm{O}_{3}$ 和 $\mathrm{CaO}$ 含量, 都可以很好的反映地幔的熔体抽取程度. 研究表明, 华 北古生代岩石圈地幔有难熔的(refractory)性质，而新 生代时有大量饱满的(fertile)二辉橄榄岩(郑建平, 1999, 2009; Zhang等, 2004; Tang等, 2013). 全岩微量元 素和 Sr-Nd-Pb同位素显示，前者具有富集的(enriched) 地幔特征，指示着长期复杂的交代历史，后者则具有 亏损的(depleted)地幔性质，且交代作用明显弱(郑建 平，1999，2009). Re-Os同位素显示古生代岩石圈地幔 具有太古宙形成年龄, 与上覆地壳年龄一致, 壳幔是耦 合的, 而新生代岩石圈地幔形成年龄新, 只有鹤壁等少 数地点有太古代年龄记录(Zheng等, 2001; Gao等, 2002; Wu等, 2003; Xu等, 2006, 2008; Zhang等, 2008; Liu等, 2011), 壳幔总体上是不耦合的. 温压计算表明, 

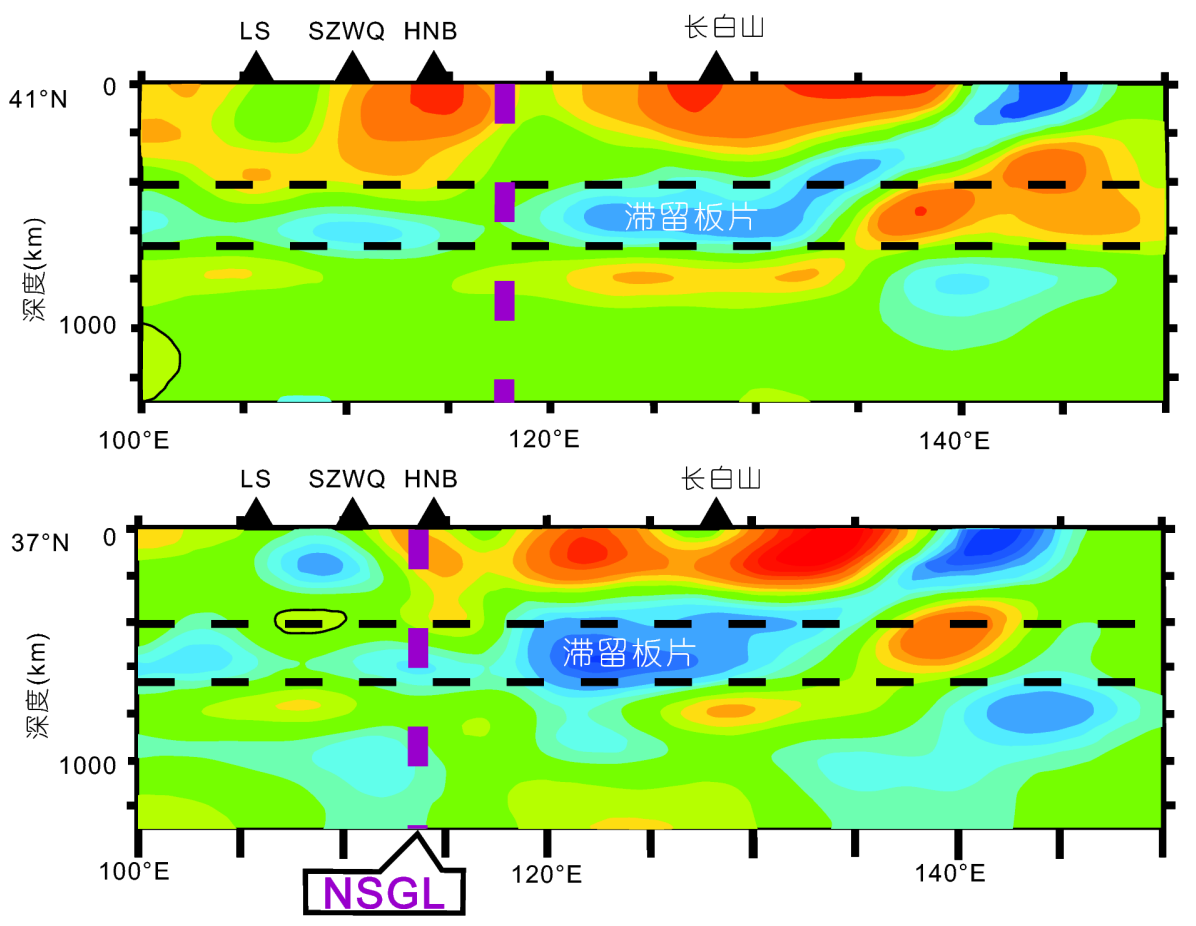

图 2 过 $41^{\circ} \mathrm{N}$ 和 $37^{\circ} \mathrm{N}$ 处地震层析成像剖面

据Zhao等(2009)和Niu(2014). LS, 狼山; SZWQ, 四子王旗; HNB, 汉诺坝; NSGL-(红色断线), 南北重力梯度带

古生代华北具有较低的地热梯度 $\left(\sim 40 \mathrm{~mW} \mathrm{~m}^{-2}\right.$; Griffin 等, 1999; Xu, 2001), 与世界其他典型克拉通类似, 而新 生代地热梯度较高( $\left.80 \mathrm{~mW} \mathrm{~m}^{-2} ; \mathrm{Xu}, 2001\right)$, 明显不同 于克拉通的情况. 因此, 华北岩石圈的厚度、性质和地 温梯度在中生代发生了重要的转变, 古老难熔、巨厚 低地温的克拉通型岩石圈地幔转变为年轻饱满、薄的 大洋型岩石圈地幔, 即中生代发生了地幔置换作用(郑 建平, 1999, 2009; Zheng等, 2007).

郯庐岩石圈深大断裂带内部新生代玄武岩中的地 幔橄榄岩包体(图1b), 如山旺和女山等地的, 主要是饱 满的二辉橄榄岩, 缺乏难熔的方辉橄榄岩(Rudnick等, 2004; Xu X S等, 2013; Park和Jung, 2015), 暗示古老 难熔地幔已被强烈置换; 远离断裂带的橄榄岩包体主 要是过渡型的二辉橄榄岩, 如阜新、辉南、宽甸和栖 霞等地的; 而位于块体核部的鹤壁玄武岩中橄榄岩包 体主体为尖晶石相方辉橄榄岩, 属古老难熔地幔的浅 部残留(Zheng等, 2001; Sun等, 2012). 这种地幔性质 的空间差异指示岩石圈深大断裂在地幔置换中起重要 作用, 即太平洋俯冲导致软流圈物质上涌, 岩石圈断裂 带为软流圈物质上涌提供通道, 是岩石圈地幔改造和
最终置换的优先发生区(Zheng等, 1998, 2007).

与地块内部岩石圈深大断裂带类似, 华北南缘和 东缘的深部岩石圈也经历了类似的改造作用. Zheng 等(2006a，2008a，2014)对信阳中生代( 160Ma)火山岩 中橄榄岩、麻粒岩等捕虏体研究发现, 华北南缘深部 岩石圈具有上老下新的年龄结构, 岩石圈地幔的性质 与典型太古代克拉通地幔有一定的差异, 受明显来自 俯冲华南陆壳释放流体的交代改造; 大别-苏鲁地区的 造山带橄榄岩地体与南缘岩石圈地幔有明显的亲缘性 (Zheng等, 2006b, 2006c, 2008b, 2014; Chen Y等, 2017). 此外, 位于北朝鲜的三叠纪金伯利岩中的地幔橄榄岩 包体体现古老与新生地幔共存的特点(Yang等, 2010).

在华北北缘中段(如汉诺坝)的火成碳酸岩中发现 含有碳化硅、金刚石等超高压还原矿物。这些碳酸岩 具有沉积碳酸盐的微量元素和同位素组成特征, 被解 释为俯冲沉积碳酸盐熔融作用所形成, 可能与古亚洲 洋俯冲对华北北缘岩石圈的改造有关(Chen等，2016). 最近我们在北缘西段的狼山新生代玄武岩中新发现了 橄榄岩包体(图1b), 它们均为尖晶石相二辉橄榄岩, 与 华北东部的新生饱满地幔类似. 该区的地壳基底主要 
是太古代-古元古代(Wang Z Z等, 2016), 如果按照古老 地壳下覆地幔也是古老的关系(Griffin等, 1999), 该区 先存的克拉通型地幔也可能也被新生饱满地幔置换. 我们认为北缘东段(阜新、宽甸、辉南)的饱满地幔 (Xu等, 2003; Zheng等, 2007; Xu R 等, 2013)可能与太平 洋俯冲作用关系密切, 而中段特别是西段, 临近古亚洲 洋构造域而远离太平洋构造域(朱日祥等, 2012), 其地 幔改造和置换作用可能与古亚洲洋俯冲作用关系更 密切.

综上所述，华北深部岩石圈在时空上是不均一的. 时间上，古生代华北深部岩石圈地幔是典型的克拉通 型地幔(古老、巨厚、难熔)，新生代时则已经不同程 度地被大洋型地幔(年轻、薄、饱满)所置换; 空间上, 板块边缘的克拉通型地幔已经被改造并置换为大洋型 地幔, 深大断裂也是地幔置换作用的优先发生区域, 而 板块内部还有克拉通型地幔残留. 因此, 现今华北岩石 圈地幔的格局可能是周边板块俯冲碰撞和块体内部薄 弱带复杂壳幔过程等共同作用的结果.

\section{4 燕山褶断带}

中生代的华北地块，除深部的岩石圈地幔发生置 换作用外，浅部的地壳变形早已引起国内外学者的广 泛关注(Davis等, 2001; 赵越等, 2004; 董树文等, 2007; 张岳桥等，2007). 中国学者把这些变形称为“燕山运 动”, 最初由Wong(1927)提出, 意指发生在燕山地区的 中晚侏罗世的重大构造事件，包括中侏罗世晚期和侏 罗世末期的两次挤压构造运动(燕山运动 $\mathrm{A} 、 \mathrm{~B}$ 幕)及 期间的中间幕. A幕以髺䯽山组-蓝旗组-九龙山组火山 岩与下伏的南大岭组-兴隆沟组之间的角度不整合为 代表, B幕以张家口组-东岭台组-义县组火山岩与下伏 后城组-土城子组火山碎屑岩之间的角度不整合为代 表，中间幕以髺䯽山组和蓝旗组的火山岩为代表(图3; 赵越等, 2004; 张岳桥等, 2007). 髺䯽山组作为燕山运 动的底界，其形成时代被认为介于 $160 \sim 152 \mathrm{Ma}(\mathrm{Hu}$ 等, 2010; 李振宏等, 2014; Li C M等, 2016), 九龙山组为 代表的区域性砾岩代表燕山运动最早的沉积响应(张 宏仁等, 2013; 李海龙等, 2014; 李振宏等, 2014; Li C M 等，2016)，其形成时代介于170 161 Ma(王永超等, 2016)，张家口组和土城子组分别作为 $B$ 幕的底界和中 间幕的顶界，其年龄分别是 $135 \mathrm{Ma}$ (牛宝贵等, 2003)和
147 136Ma(张宏等，2008)，因此燕山运动 $\mathrm{B}$ 幕的时间 下限为 136Ma; 燕山运动的时间上限存较大争议, 董 树文等(2007)认为地球磁场宁静期的终止时间 ( $~ 84 \mathrm{Ma})$ 是燕山运动的时间上限.

燕山运动 $\mathrm{A}$ 幕的挤压作用在区域上表现为一系列 的构造-岩浆-沉积记录. 其中, 北缘大青山地区的特大 型东西向的逆冲推覆构造, 被认为是蒙古-鄂霍次克洋 关闭的远程效应(Zheng等, 1996; 郑亚东等, 2000), 而 蒙古-鄂霍次克洋南缘的额尔古纳地区则以 $\mathrm{S}$ 型花岗岩 岩浆活动为特征, 被认为是区域性挤压作用的结果(许 文良等, 2013). 此外, 九龙山组东西向的原型盆地中古 水流方向以SSW为主, 显示盆地北侧显著抬升, 沉积学 分析显示该组砾岩为挤压背景下快速堆积产物(王永 超等, 2016). 在燕山运动 $\mathrm{A}$ 幕之后, 髺䯽山组和蓝旗组 的火山岩及同时代富含暗色微粒包体的花岗岩, 如辽 西的海棠山、医巫问山及北京地区的云蒙山岩基，可 能标志着南北向挤压作用之后的松弛(王永超等, 2016). 值得注意的是，华北的东部(辽西)地区晚三叠 世-侏罗纪的挤压构造是北东向的，可能是受“大华南 板块”汇聚的影响(Li等, 2017a).

燕山运动 $\mathrm{B}$ 幕以NNW-SSE的挤压作用为特征，表 现为区域性的不整合和逆冲断层. 燕山地区云蒙山岩 基北侧的四合堂NNE-SSW向逆冲带的活动时间为 140 137Ma(Zhu等, 2015), 与后城组-土城子组砾岩的 沉积年龄基本一致(张宏等, 2008), 被认为是燕山运动 $\mathrm{B}$ 幕的构造-成盆记录. 在燕山运动 $\mathrm{B}$ 幕挤压的同时, 东 北大兴安岭发育有玛尼吐组碱性流纹岩和吉祥峰组流 纹岩(具A型花岗岩特征), 暗示东部地区早白严世早期 已经处于拉张环境, 被解释为蒙古-鄂霍次克带碰撞后 伸展的结果(王建国等, 2013; 许文良等, 2013). 在早白 严世晚期至新生代，中国东部一系列NE的正断层(张 必龙等，2012；Zhu等，2015)、变质核杂岩(Wang等, 2011，2012)以及沉积盆地(张岳桥等，2004; 张岳桥和 董树文, 2008; 李理等, 2015)的形成标志着中国东部处 于伸展背景，可能与古太平洋板块俯冲及弧后伸展过 程相关(张岳桥等, 2004; 张岳桥和董树文, 2008).

\section{5 岩浆作用}

华北克拉通活化的标志之一就是广泛的岩浆作 用. 在岩浆活动时空分布方面, Zhang等(2014)等作了 


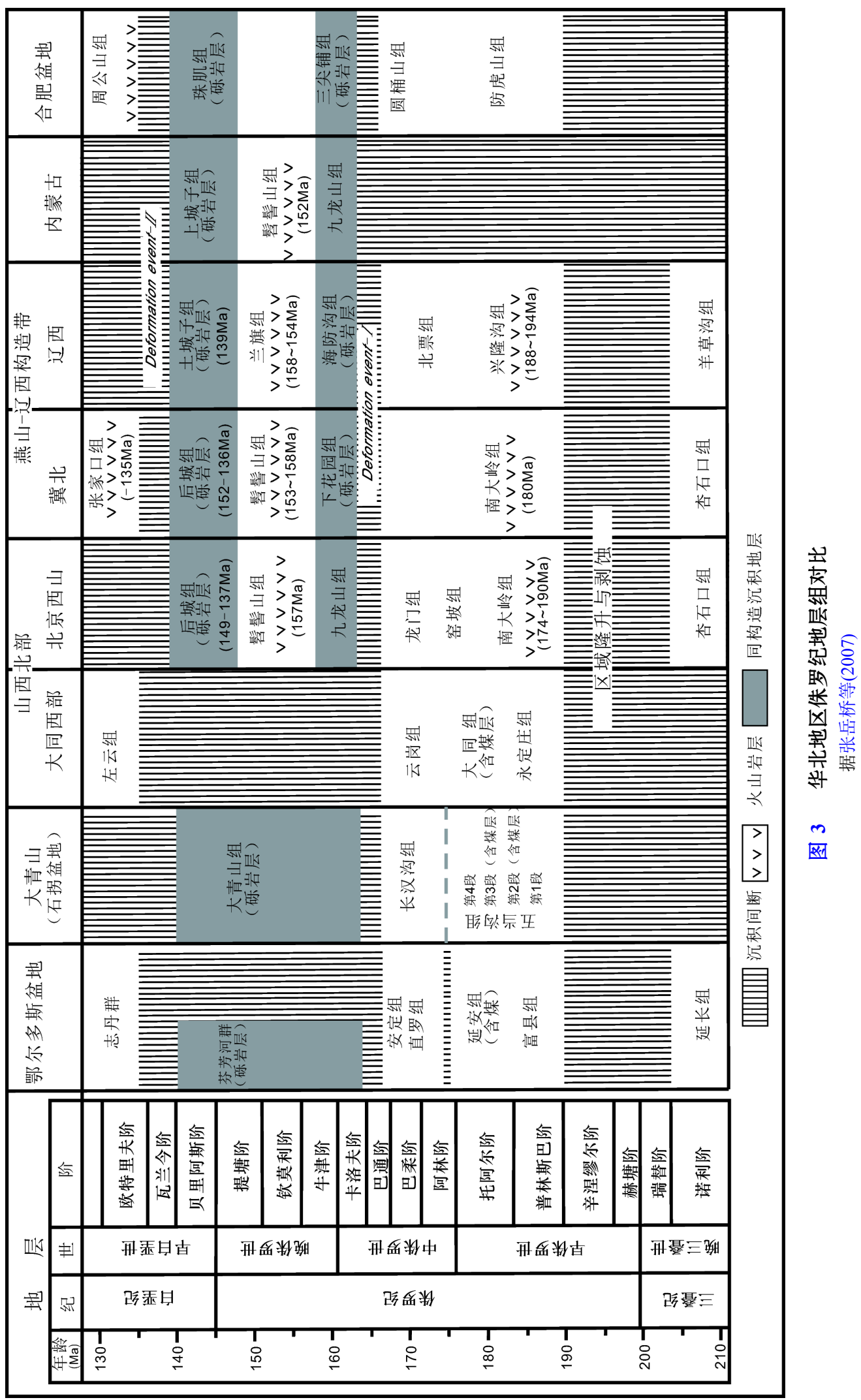


较系统的总结(图4): (1) 三叠纪(250 200Ma), 岩浆活 动局限于华北北缘(图4a和 $4 \mathrm{~b}$ ), 与索伦缝合带平行, 此 时的古亚洲洋已经闭合(Windley等, 2007), 这些岩浆 活动可能与蒙古和华北地块碰撞后伸展有关(Zhang 等, 2006, 2014). 此时, 华北地块最东边的朝鲜有金伯 利岩出露(Yang等, 2010), 金伯利岩喷发通常与古老难 熔岩石圈地幔有关(Russell等，2012；Shirey等，2013; Sparks, 2013; Brett等, 2015; Bussweiler等, 2016), 暗 示晚三叠早期华北依然存在难熔的岩石圈地幔; (2) 早 侏罗世(201 174Ma), 岩浆活动较弱(图4c), 主要集中 在燕山地区(北京西山-冀东-辽西)和东北地区; (3) 中晚侏罗世(174 145Ma), 岩浆活动有所增强(图4d), 集 中于燕山、胶辽半岛及东北地区，呈面状分布于华北 东北部; (4) 早白严世(145 100Ma), 岩浆活动达到顶 峰, 呈面状分布于整个东部, 但最集中的地区依然是燕 山地区和胶辽半岛(图4e)；(5) 晚白严世(100 66Ma), 岩浆活动进入宁静期(图4f).

在200 140Ma期间，岩浆活动由东北部向内部迁 移, 而在 $140 \mathrm{Ma}$ 以后, 岩浆活动则不断向东南方向迁移 (图5). 在140Ma以前, 太平洋板片的运动方向与欧亚大 陆边缘大致平行(Sun等, 2007), 只在东北局部存在俯 冲作用(唐杰等, 2016; Wang等, 2017), 在140Ma以后, 太平洋板片的运动方向与欧亚大陆东缘相交(Northrup 等, 1995; Sun等, 2007), 发生大规模俯冲作用, 且由于 俯冲板片的后撤，俯冲带不断向东南方向迁移(Niu, 2014). 基于以上考虑，岩浆作用的这种向东南方向的 迁移, 可能与俯冲太平洋板片后撤有关.

幔源岩浆岩的成分可以为研究地幔性质和演化提 供有价值的信息(Yang和Li, 2008; Dai等, 2016; Huang 等, 2017). 从三叠纪至白严世, 尽管不同时期的基性岩 和碱性岩都有不同程度的亏损地幔物质贡献(张辉煌 等，2006; Guo等，2007; 匡永生等，2012；Zhang等， 2014), 但它们的组成呈现出有规律的变化(图6, Liu等, 2008; Yang和Li, 2008; Meng等, 2015): (1) 110Ma以 前, 玄武岩具有岛弧型的微量元素特点, 同位素组成与 富集地幔类似，通常认为是由受到交代改造的古老克 拉通型地幔部分熔融形成(Zhang等，2004; Qian等， 2017); (2) 110Ma以后，玄武岩具有洋岛型的微量元 素组成特点, 同位素组成与亏损地幔类似, 其源区认为 有再循环的俯冲大洋板片(Guo等, 2014; Zhang等, 2015; Dai等, 2016; Li H Y等, 2016)或拆沉大陆地壳
(Liu等, 2008; Meng等, 2015)组分.

综上所述，早中生代华北的岩浆作用主体发育于 北缘和南缘, 可能是碰撞后伸展背景下来自古老地壳 和富集岩石圈地幔的熔融作用; 晚中生代以来(140Ma 以来), 岩浆作用则呈面状分布于华北东部, 且岩浆活 动有向东南迁移的趋势, 可能与俯冲太平洋板片后撤 有关. 其中, 160Ma以后幔源岩浆活动逐渐增强, 体 现华北克拉通持续拉张伸展，在 $110 \mathrm{Ma}$ 后基性岩揭示 的地幔性质由古老交代地幔转变为软流圈或具大洋型 新生岩石圈地幔, 与地幔包体研究的结果一致(Zheng 等, 2007; 郑建平, 2009).

\section{6 变质核杂岩}

华北在中生代广泛发育有变质核杂岩(图7), 它们 为研究中生代地壳变形和动力学背景提供了绝佳条 件. 这些核杂岩的空间分布具有两个特点: (1) 广泛分 布, 不局限于某一个构造域, 如在中亚、华北和华南都 有; (2) 通常分布于造山带的内部或克拉通的边缘(Lin 等, 2013b). 此外, 运动学特征有明显的对称性、等时 性和等效性. 在华北内部, 以NE-SW走向的松辽盆地渤海湾盆地为中间线, 东部(如辽西、辽南、鲁西和胶 东等地)的核杂岩向西拆离, 西部(如密云、云蒙山、 紫荆关和呼和浩特等地)的向东拆离(Lin等, $2013 \mathrm{a}$; Zhu等, 2015), 拆离的时间都在 131 115Ma(峰期为 $126 \mathrm{Ma})$, 拆离的结果都是将中下地壳 $(25 \sim 35 \mathrm{~km})$ 深处 的岩石揭露到地表(Lin等, 2013b); 在中亚造山带内部 的核杂岩, 以NE-SW向的蒙古-鄂霍次克带为中间线, 东南部(蒙古北部带)的伸展构造向NW拆离, 西北部 (贝加尔带) 的伸展构造向 SE拆离, 拆离时间为 131 125Ma (峰期为 $126 \mathrm{Ma}$ ), 结果也是将中下地壳岩石 揭露到浅表(Wang等, 2011; Lin等, 2013b). 此外, 这些 核杂岩韧性伸展的时代从西北向东南有逐渐变年轻的 趋势(Wang等, 2012), 这种时空变化可以被解释为中亚 造山带的垮塌导致中地壳滑脱, 并向东南传播, 同时叠 加了古太平洋俯冲所引起的伸展作用(Wang等, 2011).

\section{7 华北中-新生代盆地}

华北的盆-山格局主要包括: (1) 鄂尔多斯盆地; (2) 燕山构造带的盆岭省; (3) 合肥盆地; (4) 汾渭盆地和沁 

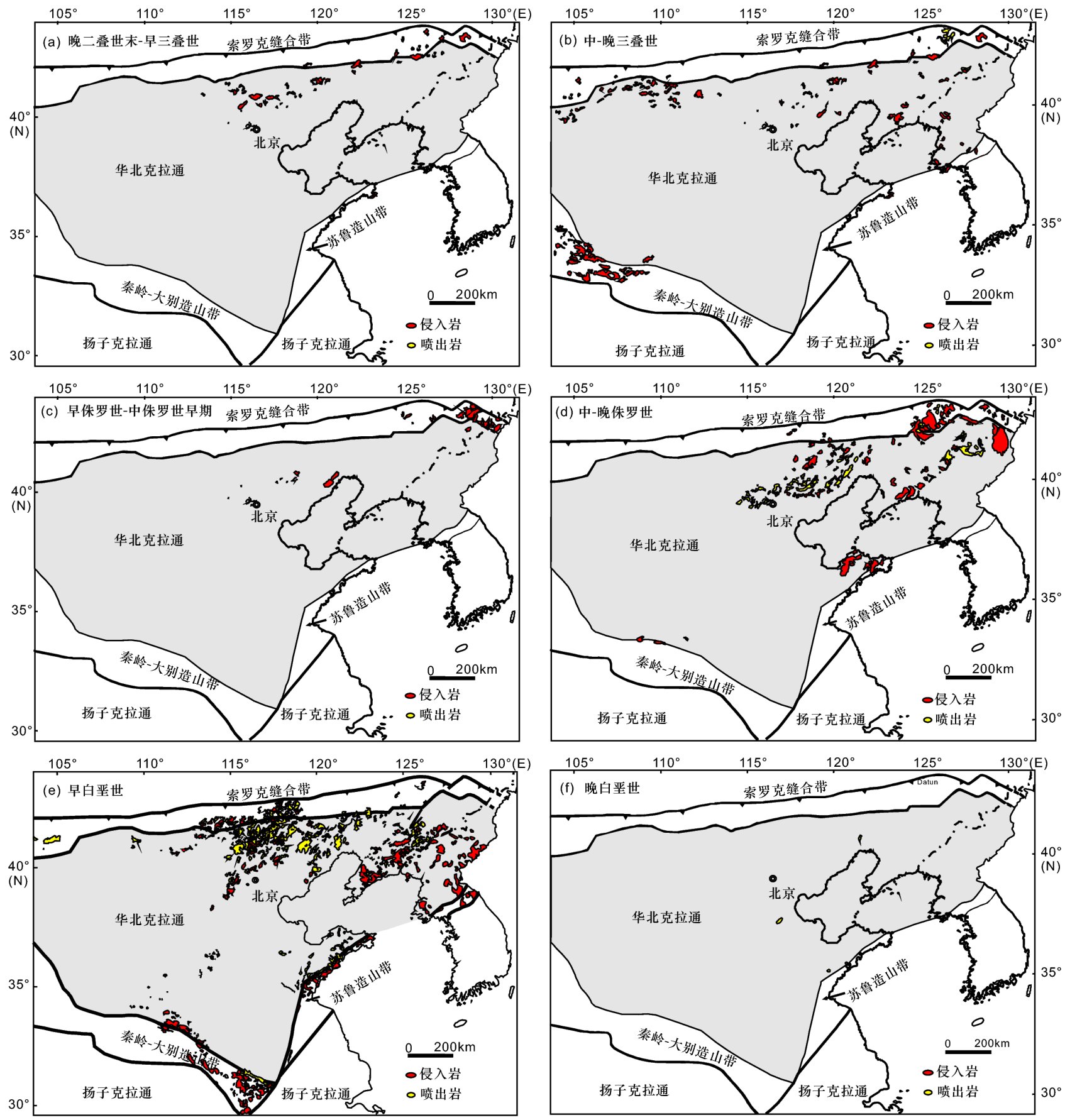

图 4 华北中生代岩浆作用的时空分布

据Zhang等(2014)

水盆地; (5) 大渤海湾盆地; (6) 胶莱盆地(图7). 其中鄂 尔多斯盆地是在前寒武纪变质基底的基础上发展而来 的大型内陆盆地，在显生宙以来除盆地边缘的部分变 形外，盆地整体变形和岩浆作用微弱，接受整体抬升
剥蚀或沉降(张岳桥和廖昌珍, 2006).

燕山构造带的盆岭省可能是多阶段构造活动叠合 的结果(刘少峰等, 2004a，2004b), 其中三叠纪原型盆 地呈近东西向广泛分布, 为挤压环境, 发生了地壳明显 


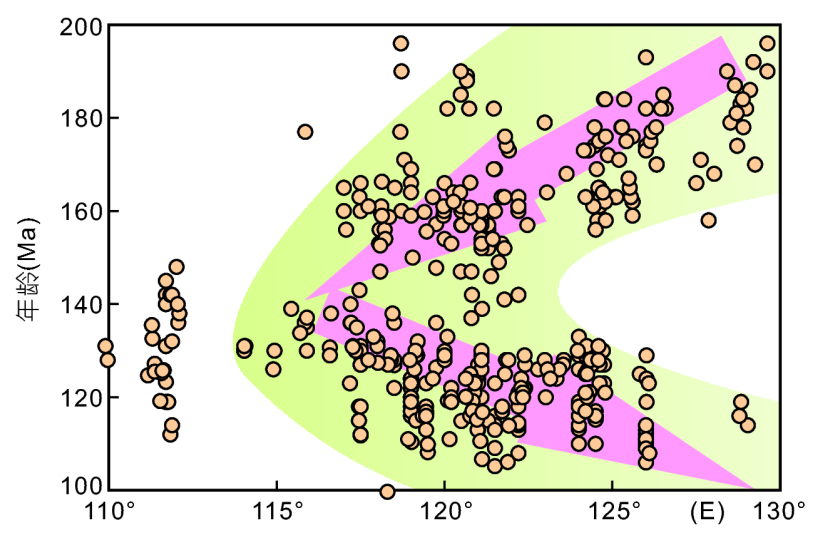

图 5 华北中生代岩浆作用迁移规律

据Zhang等(2014)及其中的参考文献

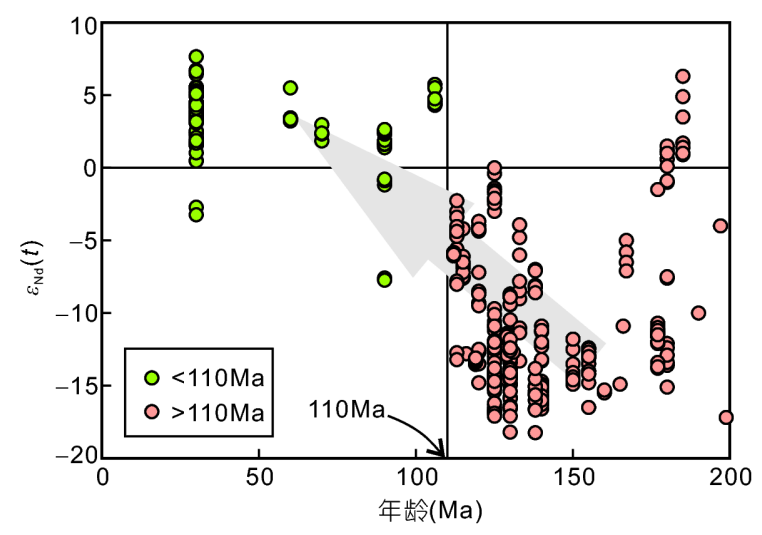

图 6 华北中-新生代基性岩和碱性岩的Nd同位素变化 情况

据Zhang等(2014)及其中的文献

缩短(崔盛芹等, 2002; 张长厚等, 2004), 可能与古亚洲 洋闭合有关(赵越等, 1994). 最近的沉积序列和年代学 研究显示, 燕山地区中三叠世-早中侏罗世地层可能不 存在不整合关系，即直到中侏罗世该地区仍处于拉张 环境(Meng等，2014)。中侏罗世-晚侏罗世早期，华北 的张性盆地被肢解, 盆地形态受逆冲断层控制, 体现区 域性的挤压作用(刘少峰等，2004a)；侏罗纪末至早白 严世早期, 四合堂逆冲断层和后城组-土城子组砾岩被 视为该地区燕山期第二次区域性挤压作用的记录. 髺 䯽山组-土城子组-张家口组的沉积时代有较大重叠, 没有明显的沉积间断，土城子组的主体沉积时代为早 白严世(张宏等，2008; 王思恩等，2013；焦润成等， 2016)，代表华北北缘陆内裂谷的起始时间，其形成可 能与古太平洋板块的俯冲作用有关(许欢等, 2011). 早
白严世盆地的格架由东西向转变为北东向，同时发育 正断层, 呈现半地堑的形势(刘少峰等, 2004a), 与此同 时松辽盆地(李娟和舒良树, 2002; Meng, 2003; Li等, 2012)和朝鲜半岛Kyongsang盆地(Chough等，2000)开 始沉降，㸚庐断裂(Zhu等，2010)、依兰-伊通断裂(顾 承串等, 2016)和敦化-密山断裂(孙晓猛等, 2008; 王枫 等, 2016; Xu等, 2017)发生左行走滑运动, 这些都可能 是古太平洋板片(伊泽奈崎板片)斜向俯冲引起的扭张 构造.

合肥盆地被认为是早侏罗世以来发育的内陆盆 地，先后受大别造山带折返和郯庐断裂带近 $\mathrm{E}-\mathrm{W}$ 向拉 张控制(Meng等，2007)：(1) 侏罗纪(200 145Ma)大别 山超高压地质体持续向南折返, 引起其北侧持续拉张 沉降, 接受来自大别山的碎屑沉积, 形成盆地早期阶 段的地层; (2) 早白严世( 145Ma)淡庐断裂带由左行 压扭断裂转换为正断层(Zhu等, 2005, 2010), 近E-W向 的拉张使合肥盆地的沉降中心向北迁移，接受来自郯 庐断裂东侧的碎屑沉积, 形成盆地晚期沉积. 因此, 合 肥盆地经历了早期山前盆地和晚期拉分盆地两个演化 阶段(Meng等, 2007). 此外, 也有观点认为合肥盆地是 与大别造山带伴生的前陆盆地(Wang等, 1997; 赵宗举 等，2000; 李忠等，2000；Liu等，2001；Liu和Zhang， 2013).

位于中部山带的汾渭盆地和沈水盆地(王莹, 2013; 许云龙，2015), 东部的大渤海湾盆地(Zhu等, 2010; 李理等, 2015)及苏鲁造山带内的胶莱盆地(翟慎 德, 2003; 佟彦明, 2007; 任凤楼等, 2008)主体上都是晚 中生代以来沿先存薄弱带发育的伸展-裂谷盆地. 在早 白严世( 140Ma)以前, 中部山带(张长厚等, 2011; 韩亚 超, 2013)和大渤海湾盆地内部(漆家福等, 2003)均发育 一系列NNE向的褶皱和伴生的逆冲断层; 早白严世 ( 140Ma)以后, NW-SE向的拉张应力使华北克拉通发 育大规模的拆离断层, 大渤海湾盆地开始沉降, 太东断 层系反转为正断层(间淑玉等, 2012); 新生代以来, 华 北中东部进入裂谷阶段, 大渤海湾盆地内部发育一系 列的裂谷盆地和隆起，如自NW-SE方向依次分布的太 行山隆起-冀中坳陷-阜城隆起-黄华坳陷-宁津隆起-济 阳坳陷-泰山隆起(李理等, 2007; 索艳慧等, 2015), 中部 山带则发育汾渭盆地和沁水盆地，苏鲁造山带则发育 胶莱盆地, 形成现今盆山相间的地貌特征. 索艳慧等 (2017)系统总结了中国东部盆地中反转构造的时空迁 


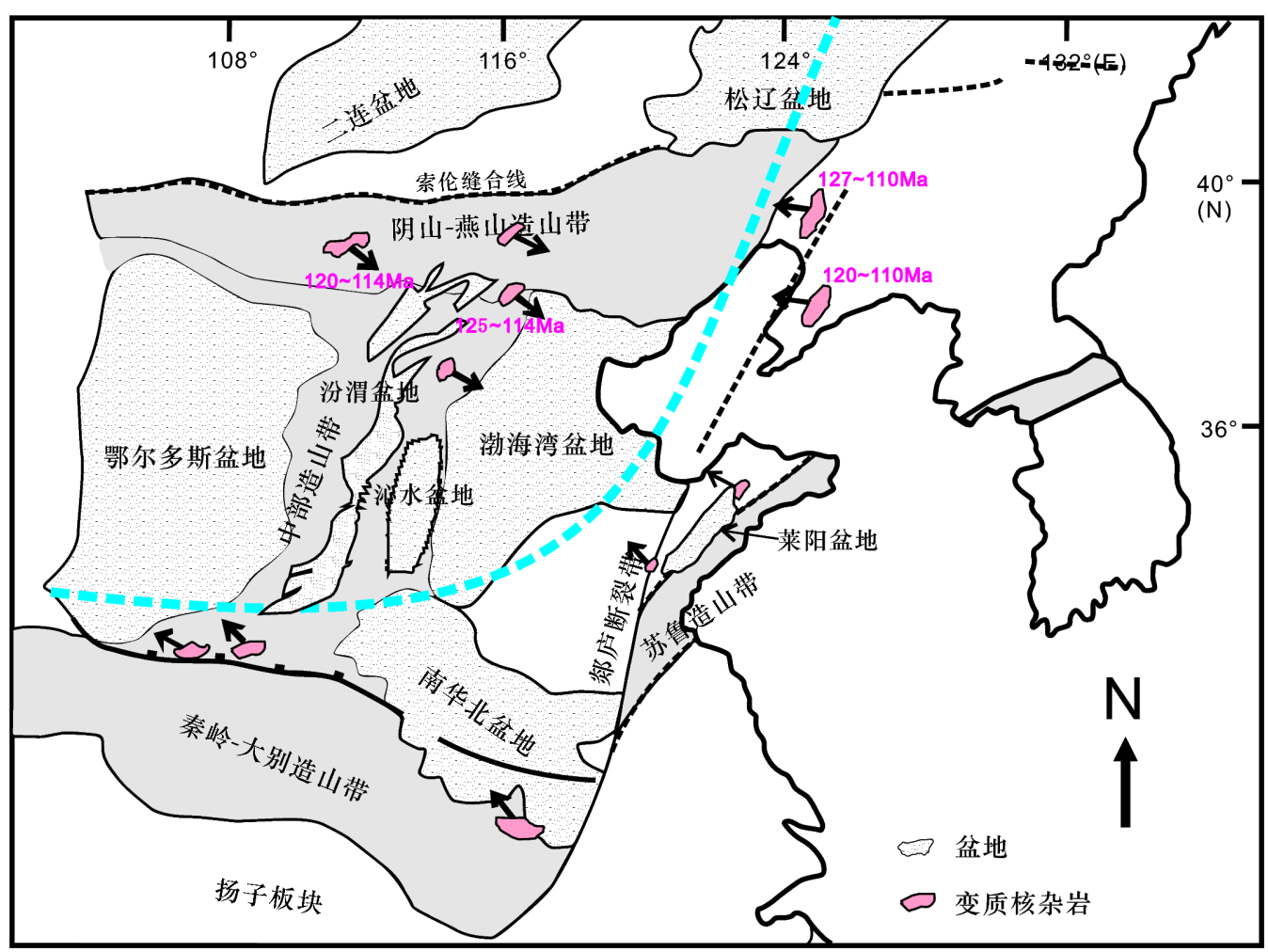

图 7 华北变质核杂岩和盆地分布

紫色字体为变质核杂岩的折返时间, 黑色箭头为正断层倾向, 蓝色虚线代表对称轴部. 资料来源: 变质核杂岩据文献Wang等(2012), 汾渭盆地 和沁水盆地的分布特征改自 $\mathrm{He}(2015)$, 盆地分布特征根据文献郑亚东等(2000)修编

移规律, 发现反转构造具有自西向东迁移的特点, 西部 沉降带(包括东北、华北、中下扬子盆地群)以中生代 末期的挤压反转为主, 东部沉降带(包括东海和南海盆 地群)以渐新世末和中新世末的新生代反转最为典型, 并认为反转构造的时空迁移与古太平洋的运动方向、 俯冲及后撤有密切联系.

\section{8 华北晚古生代以来多阶段的演化历史}

华北在古元古代完成克拉通化后保持长期稳定 (Zhai和Santosh，2011)，但自古生代以来，尤其是中生 代，周围的板片向华北俯冲、汇聚(Windley等，2010), 引发深部岩石圈地幔改造和最终置换及浅部的构造岩浆-成矿活动, 是我国乃至东亚大陆重大构造变革的 时期(赵越等, 2004; 董树文等, 2007; 张岳桥等, 2007). 演化过程可大致分为三个阶段, 即(1) 170Ma以前, 古 亚洲洋构造域和古特提斯构造域对华北南、北缘岩石
圈的改造; (2) 170 140Ma, 蒙古-鄂霍次克洋闭合对华 北的远程挤压效应和古太平洋板片运动对华北的俯 冲-剪切作用(Meng, 2003; Li等, 2012); (3) 140Ma以 后, 西太平洋俯冲和后撤引起华北持续拉张(图8).

\section{1 古亚洲洋洋和古特提斯洋俯冲对华北边缘岩 石圈的改造}

古亚洲洋向南俯冲至华北之下, 于晚古生代闭合, 使华北与蒙古地块拼合成统一陆块(Zhao等, 2013). 碰 撞拼合造成华北北缘的地壳缩短、隆升和强烈剥蚀. 北缘晚二叠世和早三叠世的逆冲断层(Davis等，2001) 和山前盆地中的碎屑锆石 ( $\mathrm{Li}$ 等, 2010)是这次挤压构 造的记录. 作为古亚洲洋俯冲的响应, 华北北缘发育 有大量的二叠纪岩浆活动(Zhang等, 2007; Zhao等, 2007). 在中三叠世及晚三叠世早期, 华北北缘出现大 量的碱性岩岩浆活动, 被解释为内蒙-华北碰撞造山带 垮塌、软流圈物质上涌导致先存的交代地幔的部分熔 


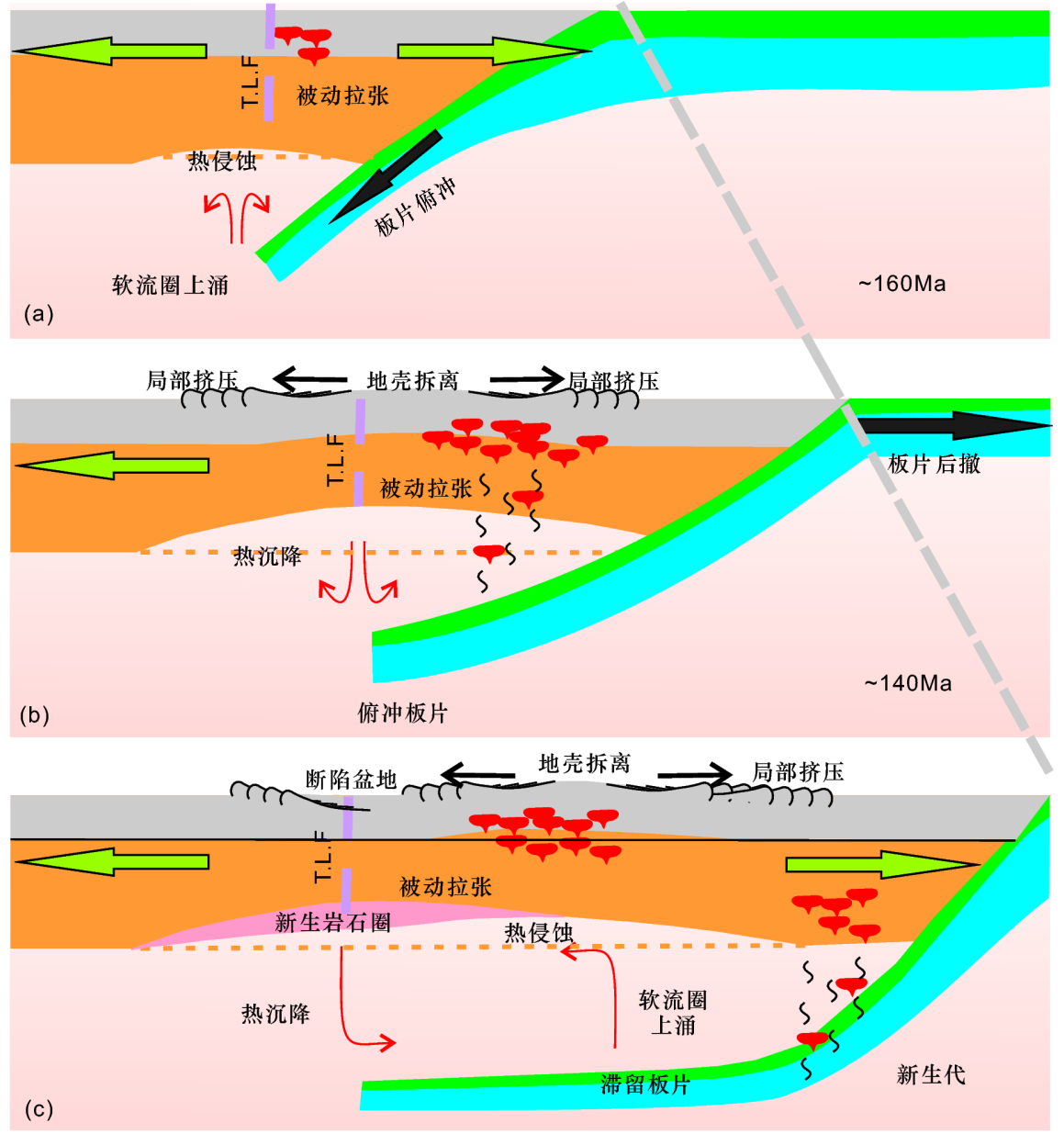

图 8 (古)太平洋俯冲与后撤引起华北深部过程和浅部响应的卡通图

(a) 160Ma, 古太平洋板片在局部地区(如东北)开始俯冲, 驱赶软流圈物质上涌, 东北地区开始处于弧后拉张环境, 产生一系列与俯冲相关的 岩浆作用. (b) 140Ma, 西太平洋板片开始大规模的NW向俯冲, 华北全面进入弧后拉张阶段, 板片俯冲引起的上涌软流圈强烈侵蚀上覆的深 部古老岩石圈地幔, 其中䣠庐断裂带处是侵蚀作用有利区域, 岩石圈地幔发生显著减薄; 软流圈的上涌也导致了莫霍面抬升, 浅部地壳发生滑 脱和拆离, 引起伸展背景下的局部挤压作用. (c) 110Ma以来, 俯冲带持续后撤, 俯冲作用导致的软流圈上涌则向东南迁移, 相关的岩浆作用也 随之迁移. 华北逐渐远离俯冲带, 降温的软流圈转变为深部新增生的岩石圈, 实现岩石圈地幔置换和小幅增厚; 浅部地壳因拉张作用而发生持 续伸展, 形成断陷盆地. (T.L.F. 㸚庐断裂)

融作用产物(Zhang等, 2012).

三叠纪华北进入板内演化的阶段. 在北缘, 与晚二 叠世和早三叠世北缘的碰撞挤压(Davis等，2001)和造 山带垮塌引起的伸展-岩浆作用(张栓宏, 2004; 张栓宏 等, 2010)不同, 晚三叠世的北缘的构造环境还有争议. 一方面，挤压构造变形(如褶皱、逆冲断层)(李海龙等, 2008; Hu等, 2010)、地层缺失及磨拉石建造等(刘少峰 等, 2004a)常被解释为古生代蒙古-华北地块碰撞的延 续. 另一方面, 新近研究显示, 三叠世盆地接受河流相 沉积, 早侏罗世的杏石口组底部为磨圆程度较好的砾 岩, 与上覆的南大岭组和下花园组地层一起具有砂岩-
粉砂岩-泥岩的演变趋势, 同时伴随有南大岭组的火山 岩喷发, 显示盆地的快速沉降(Meng等, 2014). 此外, 三 叠世-早侏罗世早期的古苏尼特左旗变质核杂岩(Davis 等，2004)和早侏罗世阴山地区大青山拉分盆地(Ritts 等，2001)也可能指示晚三叠世-早侏罗世时华北北缘 为拉张环境.

华北北缘中、新生代玄武岩中的橄榄岩包体(自 西至东出露地点依次为狼山(作者待刊资料)、四子王 旗(陈燕等，2004; Wu等，2017)、汉诺坝(Rudnick等, 2004; 余淳梅等，2006)、阜新(Zheng等，2007)、宽甸 (Xu R等, 2013)、辉南(Xu等, 2003))显示(图1b), 岩石 
圈地幔以饱满的二辉橄榄岩为主，与上覆的古老地壳 是解耦的, 暗示此前古老难熔地幔已被新生饱满地幔 置换. 东段的置换作用可能是由中-新生代的太平洋俯 冲引起(郑建平, 1999; Zheng等, 2007). 西段(如临河和 四子王旗及以西地区)远离太平洋俯冲带, 地幔改造置 换过程更可能更早, 与古生代古亚洲洋俯冲有关(Chen 等, 2016; Wang C Y等, 2016; Chen C F等, 2017; Wu等, 2017)

与古亚洲洋俯冲和蒙古-华北碰撞会对华北北缘 岩石圈的改造类似，早三叠世华南与华北大陆的深俯 冲碰撞作用(Li等，1993，2000; Zheng等，2003)给南缘 岩石圈造成了深刻的影响. 晚三叠世-早侏罗世，华北 南缘西部的秦岭地区发生陆陆碰撞(Jiang等，2010; Dong和Santosh, 2016), 俯冲板片断离引发广泛岩浆活 动(Zhang等, 2014), 东部的大别-苏鲁地区则继承了中 三叠世大陆深俯冲作用的特点，发育大量的挤压构造， 如徐州-苏州的逆冲推覆体(陈云棠和舒良树, 2000), 胶 东半岛的逆冲断层和褶皱(李三忠等, 2009), 以及鲁西 和辽东半岛地区的褶皱等(李三忠等，2009；Yang等， 2011). 侏罗纪合肥盆地的沉降可能与大别山超高压地 质体持续向南折返有关(Meng等, 2007).

中生代信阳火山岩中包体记录了南缘岩石圈上老 下新的年龄结构, 其中岩石圈地幔(Zheng等, 2006a)和 最下部的下地壳(Zheng等，2008a)记录了 230Ma的锆 石年龄，指示华南大陆俯冲碰撞作用对华北南缘深部 岩石圈的强烈改造. 苏鲁造山带地质体橄榄岩中的锆 石记录了与华北古生代金伯利岩中捕虏体类似的改造 历史，一方面指示这些橄榄岩是来自华北南缘岩石圈 地幔，另一方面也记录着华南深俯冲对华北南缘岩石 圈的深刻影响，它们都有 230Ma的改造年龄(Zheng 等, 2014).

总之，华北克拉通南、北两侧分别经历了古亚洲 洋构造域和古特提斯构造域的强烈改造或影响，经历 了弧后拉张、碰撞挤压、碰撞后伸展等构造演化过 程，在华北地块边缘深部岩石圈地幔和浅表的岩浆作 用、构造变形、盆地演化, 都有深刻的记录.

\section{2 蒙古-鄂霍次克洋闭合及古太平洋板片俯冲对 华北的重要影响}

中-晚侏罗世和早白严世早期(170 140Ma)，是华 北甚至整个东亚大陆最重要的构造-岩浆-成矿作用时
期, 表明此时壳幔作用强烈. 这一时期华北所处的主要 动力学背景包括: (1) 蒙古-华北地块和西伯利亚地块 沿着蒙古-鄂霍次克缝合带呈“剪刀口”式碰撞挤压 (Kravchinsky等, 2002; Metelkin等, 2010)及随后的造山 带垮塌伸展(许文良等，2013)；(2) 晚侏罗世古太平洋 板片(伊泽奈崎板片)向华北的斜向俯冲(Maruyama等, 1997; Takashima等, 2006; Sun等, 2007)造成的剪切作 用(徐佑德, 2009; Zhu等, 2010).

这一时期(170 140Ma), 华北最为显著的地质事件 即为“燕山运动”，即发生于 $160 \mathrm{Ma}$ 和 $140 \mathrm{Ma}$ 的两次 地壳挤压事件(燕山运动 $\mathrm{A} 、 \mathrm{~B}$ 幕，图3)及其间短暂伸 展事件(中间幕)(赵越等, 2004; 董树文等, 2007; 张岳 桥等, 2007). A 幕发生时间与蒙古-鄂霍次克海的关闭 的时间吻合, 被解释为西伯利亚地块和蒙古-华北地块 碰撞挤压的远程效应(Zhu等，2015)，中间幕的拉张事 件则为挤压作用松弛的结果(王永超等，2016). B 幕发 生时间与蒙古-鄂霍次克造山带的垮塌伸展时间对应, 作为岩石圈薄弱带的华北北缘(阴山-燕山地区)，可能 会优先发生岩石圈缩短从而吸收蒙古-鄂霍次克带内 部的伸展应变(Meng, 2003). 在燕山运动 $\mathrm{B}$ 幕发生挤压 的同时，东北地区却发育碱性火山岩(王建国等, 2013; 许文良等, 2013), 显示出拉张背景, 这可能与蒙古-鄂 霍次克洋呈“剪刀口”式闭合有关(Yang等, 1998; Kravchinsky等, 2002), 即西边的燕山地区发生陆陆碰撞挤 压时, 东边的蒙古-鄂霍次克洋可能尚未关闭(Kravchinsky等, 2002; Metelkin等, 2010).

近 140Ma时, 岩浆作用由东北地区向西迁移至华 北内部(图5), 可能与西太平洋板片运动方向逆时针旋 转(Sun等，2007)有关，俯冲作用逐渐由东北地区逐渐 扩大至整个欧亚大陆东部，东北地区记录了与古太平 洋板片俯冲相关的岩浆活动(图8a; 许文良等，2013; Wang F等, 2015). 这一阶段西太平洋板片的运动方向 与东亚大陆边缘大致平行，华北东部主要受左行压扭 性应力影响, 先存的东西向构造逐渐转为北东向(刘少 峰等, 2004a), 中部山带发生挤压变形形成北东向分布 的褶皱逆冲断层系(韩亚超, 2013), 郯庐断裂发生走滑 作用(Zhu等, 2005, 2010).

\section{3 西太平洋俯冲和后撤引起岩石圈地幔置换和 浅部山盆耦合响应}

在早白严世和新生代( 140Ma以来), 西太平洋板 
片的俯冲和后撤引起的大规模岩浆作用(Xu，2001; Zhang等, 2014)和岩石圈伸展 $(X u, 2001$; 刘少峰等, 2004a; 李理等, 2007, 2015; Zhu等, 2010; 许文良等, 2013). 与古生代的古亚洲洋俯冲和三叠纪的特提斯洋 俯冲不同的是, 晚中生代古太平洋俯冲对华北岩石圈 地幔的改造深入克拉通内部, 所引起的构造-岩浆活动 呈面状分布于整个东部(图4e). 岩浆作用优先于先存 的岩石圈薄弱带(如克拉通的边缘、深大断裂和缝合 带附近等), 且随着时间向东南迁移(图5), 这可能是太 平洋板片俯冲发生大规模俯冲和后撤及岩石圈板内薄 弱共同作用的结果:

由于俯冲板片的拖拽作用, 俯冲带受到向洋脊俯 冲方向的分力, 使东亚大陆岩石圈被动仰冲、拉张和 漂移(Niu, 2014), 先存的岩石圈薄弱带会优先发生伸 展应变(图8b), 造成浅部地壳拆离和渤海湾盆地沉降 (徐佑德，2009; 李理等，2015)及变质核杂岩的发育 (Lin等，2013b). 随着俯冲板片的后撤，中国东部逐渐 远离俯冲环境, 造成岩浆作用逐渐向东南方向迁移(图 5). 在新生代, 由于持续拉张(图8c), 位于中部山带的汾 渭盆地打开, 而渤海湾盆地则进一步发生断陷从而形 成盆岭相间的构造格局(太行山隆起-冀中坳陷-阜城隆 起-黄骅坳陷-宁津隆起-济阳坳陷-泰山隆起). 此时, 由 软流圈上涌导致的岩石圈侵蚀中心则向东南移动至浙 闽-东海地区(Su等, 2014), 形成一系列的盆岭构造.

太平洋板片的俯冲和后撤对深部岩石圈地幔也产 生深刻影响. 俯冲太平洋板片导致软流圈上涌, 岩石圈 薄弱带为软流圈上涌提供通道(Zheng等, 1998; 郑建 平，1999), 使郯庐断裂带附近的古老岩石圈地幔被侵 蚀、减薄(图8b, Zheng等, 2007), 而先存于华北北缘燕 山地区的饱满岩石圈地幔则会因太平洋板片热扰动而 优先熔融, 产生集中于燕山地区的大规模岩浆活动 (Zhang等, 2014). 随着俯冲带的后撤(Niu, 2014), 中国 东部逐渐远离俯冲带, 地温梯度不断降低, 软流圈地幔 转化为岩石圈地幔增生于岩石圈底部, 造成了大幅减 薄后的岩石圈有小幅增厚(图8c; Zheng等, 1998, 2007; $\mathrm{Xu}, 2001)$. 俯冲下去的太平洋板片则滞留在地幔转换 带中, 形成了东亚大地幔楔(Zhao等, 2009), 滞留于地 幔转换带的俯冲板片脱水进一步促进了中国东部的克 拉通活化(Niu, 2014). 因此我们认为, 西太平洋板片俯 冲和后撤是引起华北东部深部岩石圈地幔置换并导致 陆内浅部盆-山耦合的外在动力来源, 表明华北克拉通
破坏是地块内部与地块边缘、深部过程与浅部盆-山 耦合响应的综合地质记录, 它们代表着燕山运动的 本质.

\section{9 结语}

华北克拉通活化破坏是其周边多方向俯冲作用及 深部软流圈物质沿地块内部薄弱带共同作用的结果. 在中侏罗世( 170Ma) 以前, 华北北缘和南缘分别遭受 近南北向的碰撞挤压及碰撞后伸展, 这些作用引起了 相应的纬向分布的盆地、断裂和岩浆作用, 并对华北 地块的边缘造成了强烈的改造, 使地块的边缘不再具 有刚性克拉通的特点, 成为后期构造-岩浆活动的多发 区域; 晚中生代以来, 克拉通破坏主要表现为古太平洋 板块俯冲导致软流圈物质上涌、岩石圈发生减薄和浅 部地壳滑脱, 薄弱带处(中部山带)出现褶皱和逆冲, 实 现伸展背景下的局部挤压; 板块后撤则使上涌的软流 圈物质回落实现地幔置换小幅增生和浅部地壳断陷, 实现伸展背景下的成盆和地壳变形. 因此, 西太平洋板 片俯冲和后撤是引起华北东部深部岩石圈地幔置换并 导致陆内浅部盆-山耦合的外在动力来源, 表明华北克 拉通破坏, 或燕山运动, 是地块内部与地块边缘、深部 过程与浅部盆一山耦合响应的综合地质记录.

致谢感谢朱日祥院士的组稿, 郑永飞院士和三位审稿 人的修改建议。

\section{参考文献}

陈国达．1956．中国地台“活化区”的实例并着重讨论“华夏古陆”问 题. 地质学报, 36: 239-271

陈燕, 吴泰然, 许绚, 张双涛. 2004. 内蒙古四子王旗东八号中新世含 深源捕虏体富钾橄榄玄武岩的发现及其意义. 高校地质学报, 10: 586-593

陈云棠, 舒良树. 2000. 淮北夹沟-桃山集地区推覆构造研究. 大地构 造与成矿学, 24: 208-217

崔盛芹, 李锦蓉, 吴珍汉, 易明初, 沈淑敏, 尹华仁, 马寅生. 2002. 燕 山地区中新生代陆内造山作用. 北京: 地质出版社

董树文, 张岳桥, 龙长兴, 杨振宇, 季强, 王涛, 胡建民, 陈宣华. 2007. 中国侏罗纪构造变革与燕山运动新诠释. 地质学报, 81：14491461

顾承串, 朱光, 翟明见, 林少泽, 宋利宏, 刘备. 2016. 依兰-伊通断裂带 中生代走滑构造特征与起源时代. 中国科学: 地球科学, 46: 
$1579-1601$

韩亚超. 2013. 大同盆地西缘中生代逆冲断构造变形研究. 硕士学位 论文. 北京: 中国地质大学

焦润成, 贺瑾瑞, 王荣荣, 王强强, 回广骥. 2016. 北京北部千家店土 城子组LA-ICP-MS锆石U-Pb同位素测年及启示. 中国地质，43: 1750-1760

匡永生, 庞崇进, 罗震宇, 洪路兵, 钟玉婷, 邱华宁, 徐义刚. 2012. 胶 东青山群基性火山岩的Ar-Ar年代学和地球化学特征：对华北克 拉通破坏过程的启示. 岩石学报, 28: 1073-1091

李海龙, 张宏仁, 渠宏杰, 蔡向民, 王猛. 2014. 燕山运动“绪动/A幕”的 本质意义及其锆石 U-Pb年代学制约. 地质评论, 60: 1026-1042

李海龙, 张长厚, 邹云, 邓洪菱, 马君. 2008. 冀东马兰峪背斜南翼与 西部倾伏端盖层变形特征及其构造意义．地质通报，27：16981708

李娟, 舒良树. 2002. 松辽盆地中、新生代构造特征及其演化. 南京 大学学报, 38: 525-531

李理, 赵利, 刘建海, 房贤云. 2015. 渤海湾盆地晚中生代-新生代伸展 和走滑构造及深部背景. 地质科学, 50: 446-472

李理, 钟大㐘, 时秀朋. 2007. 鲁西隆起和济阳坳陷新生代隆坳耦合 关系. 地质学报, 81: 1215-1228

李三忠, 刘釒金, 索艳慧, 刘丽萍, 钱存超, 刘晓春, 张国伟, 赵国春. 2009. 华北克拉通东部地块和大别-苏鲁造山带印支期褶皱-逆冲 构造与动力学背景. 岩石学报, 25: 3-21

李振宏, 董树文, 渠宏杰. 2014. 华北克拉通北缘侏罗纪造山过程及 关键时限的沉积证据. 吉林大学学报(地球科学版), 44: 15531574

李忠, 刘少峰, 张金芳, 王清晨. 2003. 燕山典型盆地充填序列及迁移 特征：对中生代构造转折的响应. 中国科学 D辑：地球科学, 33: 931-940

李忠, 孙枢, 李任伟, 江茂生. 2000. 合肥盆地中生代充填序列及其对 大别山造山作用的指示. 中国科学 $\mathrm{D}$ 辑: 地球科学, 33: 256-263

刘少峰, 李忠, 张金芳. 2004a. 燕山地区中生代盆地演化及构造体制. 中国科学 D辑: 地球科学, 34: 19-31

刘少峰, 张金芳, 李忠, 王清晨. 2004b. 燕山承德地区晚侏罗世盆地 充填记录及对盆缘构造作用的指示. 地学前缘, 11: 245-254

毛景文, 谢桂青, 张作衡, 李晓峰, 王义天, 张长青, 李永峰. 2005. 中 国北方中生代大规模成矿作用的期次及其地球动力学背景. 岩 石学报, 21: 169-188

牛宝贵, 和政军, 宋彪, 任纪舜. 2003. 张家口组火山岩SHRIMP定年 及其重大意义. 地质通报, 22: 140-141

漆家福, 于福生, 陆克政, 周建勋, 王子显 杨桥. 2003. 渤海湾地区的 中生代盆地构造概论. 地学前缘, 10: 199-206

任凤楼, 柳忠泉, 邱连贵, 韩立国, 张岳桥, 曹忠祥. 2008. 胶莱盆地莱 阳期原型盆地恢复. 沉积学报, 26: 221-233

孙晓猛, 刘永江, 孙庆春, 韩国卿, 王书琴, 王英德. 2008. 敦密断裂带 走滑运动的 ${ }^{40} \mathrm{Ar}{ }^{39} \mathrm{Ar}$ 年代学证据. 吉林大学学报, 38: 965-972
索艳慧, 李三忠, 曹现志, 李胥瑶, 刘釒軎, 花花. 2017. 中国东部中新 生代反转构造及其记录的大洋板块俯冲过程. 地学前缘, 24 : 249-267

索艳慧, 李三忠, 许立青, 戴黎明, 刘金金, 郭玲莉, 曹花花, Валерьевна Д Л, Roya N, 王鹏程, 周立宏, 楼达. 2015. 渤海湾盆地大歧口凹 陷新生代构造演化与盆地原型. 地质科学, 50: 473-488

唐杰, 许文良, 王枫. 2016. 东北亚早中生代火成岩组合的时空变异: 对古太平洋板块俯冲开始时间的制约. 矿物岩石地球化学通报, 35: $1181-1194$

佟彦明. 2007. 胶莱盆地构造演化研究. 博士学位论文. 武汉: 中国地 质大学

王枫, 许文良, 葛文春, 杨浩, 裴福萍, 吴韦. 2016. 敦化-密山断裂带的 平移距离: 来自松嫩-张广才岭-佳木斯-兴凯地块古生代-中生代 岩浆作用的制约. 岩石学报, 32: 1129-1140

王建国, 和钟华, 许文良. 2013. 大兴安岭南部钠闪石流纹岩的岩石 成因: 年代学和地球化学证据. 岩石学报, 29: 853-863

王思恩, 高林志, 万晓樵, 宋彪. 2013. 辽西-冀北地区土城子组的地质 时代、年龄及其国际地层对比. 地质通报, 32: 1673-1690

王䒯. 2013. 沁水盆地中新生代构造变形及构造应力场特征. 博士学 位论文. 南京: 南京大学

王永超, 董树文, 施炜, 岑敏, 李江瑜. 2016. 华北晚中生代构造演化 过程——根据太行山北部盆地沉积记录. 地球学报, 37: 35-45

吴福元, 徐义刚, 高山, 郑建平. 2008. 华北岩石圈减薄与克拉通破坏 研究的主要学术争论. 岩石学报, 24: 1145-1174

徐刚, 赵越, 高锐, 李秋生, 胡建民, 刘晓文, 吴海, 杨富全, 张栓宏, 管 烨, 张季生, 白金, 匡朝阳, 王海燕. 2006. 燕山禇断带中生代盆地 变形-板内变形过程的记录——以下板城、承德-上板城、北台 盆地为例. 地球学报, 27: 1-12

徐佑德. 2009. 郯庐断裂带构造演化特征及其与相邻盆地的关系. 博 士学位论文. 合肥: 合肥工业大学

许欢, 柳永清, 刘燕学, 旷红伟. 2011. 银山-燕山地区晚侏罗世-早白 普世土城子组地层沉积特征及盆地构造属性分析. 地学前缘, 18: $88-106$

许文良, 王枫, 裴福萍, 孟恩, 唐杰, 徐美君, 王伟. 2013. 中国东北中 生代构造体制与区域成矿背景：来自中生代火山岩组合时空变 化的制约. 岩石学报, 29: 339-353

许云龙. 2015. 大同新生代断陷盆地形成与演化. 硕士学位论文. 太 原: 太原理工大学

问淑玉, 张进江, 王晓先, 卢丹, 王丽斌. 2012. 太行山东缘断裂南支 断层性质及断层泥 $\mathrm{K}-\mathrm{Ar}$ 同位素定年. 地质科学, 47: 1-12

余淳梅, 郑建平, Griffin W L. 2006. 汉诺坝橄榄岩捕虏体的单斜辉石 LAM-ICPMS分析及其岩石圈地幔演化意义. 地球科学——国 地质大学学报, 31: 93-100

翟明国. 2008. 华北克拉通中生代破坏前的岩石圈地幔与下地壳. 岩 石学报, 24: 2185-2204

翟明国. 2011. 克拉通化与华北陆块的形成. 中国科学: 地球科学, 41: 
$1037-1046$

翟慎德. 2003. 胶莱盆地莱阳凹陷构造特征及演化. 石油实验地质, 25: $137-142$

张必龙, 朱光, 谢成龙, 刘小明, 陈印. 2012. 辽西医巫问山晚侏罗世 伸展事件的时限: 来自同构造岩脉的年代学证据. 高校地质学报, 18: $647-660$

张宏, 韦忠良, 柳晓明, 李栋. 2008. 冀北-辽西地区土城子组的LAICP-MS测年. 中国科学D辑: 地球科学, 38: 960-970

张宏仁, 张永康, 蔡向民, 渠宏杰, 李海龙, 王猛. 2013. 燕山运动的 “绪动”一—燕山事件. 地质学报, 87: 1779-1790

张辉煌, 徐义刚, 葛文春, 马金龙. 2006. 吉林伊通-大屯地区晚中生 代-新生代玄武岩的地球化学特征及其意义. 岩石学报, 22: 15791596

张栓宏. 2004. 燕山构造带内蒙古隆起东段晚古生代-早中生代构造 岩浆活动及其地质意义. 博士学位论文. 北京: 中国地质科学院

张栓宏, 赵越, 胡建民, 宋彪, 刘建, 吴海. 2010. 华北地块北缘晚古生 代-早中生代岩浆活动期次、特征及构造背景. 岩石矿物学杂志, 29: 824-842

张岳桥, 董树文, 赵越, 张田. 2007. 华北侏罗纪大地构造: 综评与新 认识. 地质学报, 81: 1462-1480

张岳桥, 董树文. 2008. 㸚庐断裂带中生代构造演化史: 进展与新认 识. 地质通报, 27: 1371-1390

张岳桥, 廖昌珍. 2006. 晚中生代-新生代构造体制转折与鄂尔多斯盆 地改造. 中国地质, 33: 28-40

张岳桥, 赵越, 董树文, 杨农. 2004. 中国东部及邻区早白严世裂陷盆 地构造演化阶段. 地学前缘, 11: 123-133

张长厚, 李程明, 邓洪菱, 刘阳, 刘否, 魏波 李寒滨, 刘孜. 2011. 燕山太行山北段中生代收缩变形与华北克拉通破坏. 中国科学: 地球 科学, 41: 593-617

张长厚, 吴淦国, 徐德斌, 王根厚, 孙卫华. 2004. 燕山板内造山带中 段中生代构造格局与构造演化. 地质通报, 23: 864-875

赵越, 徐刚, 张栓宏, 杨振宇, 张岳桥, 胡建民. 2004. 燕山运动与东亚 构造体制的转变. 地学前缘, 11: 319-328

赵越, 杨振宇, 马醒华. 1994. 东亚大地构造发展的重要转折. 地质科 学, 29: 105-119

赵宗举, 杨树锋, 陈汉林, 竺国强, 周进高. 2000. 合肥盆地基底构造 属性. 地质科学, 35: 288-296

郑建平. 1999. 中国东部地幔置换作用与中新生代岩石圈减薄. 北京: 中国地质大学出版社

郑建平. 2009. 不同时空背景幔源物质对比与华北深部岩石圈破坏 和增生置换过程. 科学通报, 54: 1990-2007

郑建平, 路凤香, O'Reilly S Y, Griffin W L, 张明. 1999. 华北地台东部 古生代与新生代岩石圈地幔特征及其演化. 地质学报, 73: 47-56 郑亚东, Davis G A, 王琮, Darby B J, 张长厚. 2000. 燕山带中生代主 要构造事件与板块构造背景问题. 地质学报, 74: 289-302

郑永飞. 2008. 超高压变质与大陆碰撞研究进展：以大别-苏鲁造山
带为例. 科学通报, 53: 2129-2152

朱日祥, 陈凌, 吴福元, 刘俊来. 2011. 华北克拉通破坏的时间、范围 与机制. 中国科学: 地球科学, 41: 583-592

朱日祥, 徐义刚, 朱光, 张宏福, 夏群科, 郑天愉. 2012. 华北克拉通破 坏. 中国科学: 地球科学, 42: 1135-1159

朱日祥, 郑天愉. 2009. 华北克拉通破坏机制与古元古代板块构造体 系. 科学通报, 54: 1950-1961

Brett R C, Russell J K, Andrews G D M, Jones T J. 2015. The ascent of kimberlite: Insights from olivine. Earth Planet Sci Lett, 424: 119131

Bussweiler Y, Stone R S, Pearson D G, Luth R W, Stachel T, Kjarsgaard B A, Menzies A. 2016. The evolution of calcite-bearing kimberlites by melt-rock reaction: Evidence from polymineralic inclusions within clinopyroxene and garnet megacrysts from Lac de Gras kimberlites, Canada. Contrib Mineral Petrol, 171: 65

Carlson R W, Pearson D G, Boyd F R, Shirey S B, Irvine G, Menzies A, Gurney J J. 1999. Re-Os systematics of lithospheric peridotites: Implications for lithosphere formation and preservation. In: 7th International Kimnerlite Conference. Cape Town: Red Roof Design. 99-108

Carlson R W, Pearson D G, James D E. 2005. Physical, chemical, and chronological characteristics of continental mantle. Rev Geophys, 43: RG1001

Chen C F, Liu Y S, Foley S F, Ducea M N, Geng X L, Zhang W, Xu R, Hu Z C, Zhou L, Wang Z C. 2017. Carbonated sediment recycling and its contribution to lithospheric refertilization under the northern North China Craton. Chem Geol, 466: 641-653

Chen C F, Liu Y S, Foley S F, Ducea M N, He D T, Hu Z C, Chen W, Zong K Q. 2016. Paleo-Asian oceanic slab under the North China craton revealed by carbonatites derived from subducted limestones. Geology, 44: 1039-1042

Chen Y, Su B, Chu Z Y. 2017. Modification of an ancient subcontinental lithospheric mantle by continental subduction: Insight from the Maowu garnet peridotites in the Dabie UHP belt, Eastern China. Lithos, 278-281: 54-71

Chough S K, Kwon S T, Ree J H, Choi D K. 2000. Tectonic and sedimentary evolution of the Korean peninsula: A review and new view. Earth-Sci Rev, 52: 175-235

Chough S K, Sohn Y K. 2010. Tectonic and sedimentary evolution of a Cretaceous continental arc-backarc system in the Korean peninsula: New view. Earth-Sci Rev, 101: 225-249

Dai L Q, Zheng Y F, Zhao Z F. 2016. Termination time of peak decratonization in North China: Geochemical evidence from mafic igneous rocks. Lithos, 240-243: 327-336

Dave R, Li A B. 2016. Destruction of the Wyoming craton: Seismic evidence and geodynamic processes. Geology, 44: 883-886 
Davis G A, Xu B, Zheng Y D, Zhang W J. 2004. Indosinian extension in the Solonkersuture zone: The Sonid Zuoqi metamorphic core complex, Inner Mongolia, China. Earth Sci Front, 11: 135-144

Davis G A, Zheng Y D, Wang C. 2001. Mesozoic tectonic evolution of the Yanshan fold and thrust belt, with emphasis on Hebei and Liaoning provinces, northern China. In: Hendrix M S, Davis G A, eds. Paleozoic and Mesozoic Tectonic Evolution of Central AsiaFrom Continental Assembly to Intracontinental Deformation. McLean: Geological Society of America Memoir. 171-197

Dong Y P, Santosh M. 2016. Tectonic architecture and multiple orogeny of the Qinling Orogenic Belt, Central China. Gondwana Res, 29: 1-40

Dong Y P, Zhang G W, Hauzenberger C, Neubauer F, Yang Z, Liu X M. 2011. Palaeozoic tectonics and evolutionary history of the Qinling orogen: Evidence from geochemistry and geochronology of ophiolite and related volcanic rocks. Lithos, 122: 39-56

Fukao Y, Obayashi M, Nakakuki T. 2009. Stagnant slab: A review. Annu Rev Earth Planet Sci, 37: 19-46

Gao S, Rudnick R L, Carlson R W, McDonough W F, Liu Y S. 2002. Re-Os evidence for replacement of ancient mantle lithosphere beneath the North China craton. Earth Planet Sci Lett, 198: 307-322

Gao S, Zhang B R, Gu X M, Xie Q L, Gao C L, Guo X M. 1995. Silurian-Devonian provenance changes of South Qinling basins: Implications for accretion of the Yangtze (South China) to the North China cratons. Tectonophysics, 250: 183-197

Griffin W L, O’Reilly S Y, Abe N, Aulbach S, Davies R M, Pearson N J, Doyle B J, Kivi K. 2003. The origin and evolution of Archean lithospheric mantle. Precambrian Res, 127: 19-41

Griffin W L, O'Reilly S Y, Ryan C G. 1999. The composition and origin of sunbcontinental lithospheric mantle. In: Fei Y W, Bertka C M, Mysen B O, eds. Mantle Petrology: Field observations and High Pressure Experimentation: Attribute to Francis R. (Joe) Boyd. Houston: Geochemical Society Special Publication

Guo F, Fan W M, Li X Y, Li C W. 2007. Geochemistry of Mesozoic mafic volcanic rocks from the Yanshan belt in the northern margin of the North China Block: Relations with post-collisional lithospheric extension. In: Zhai M G, Windley B F, Kusky T M, Meng Q R, eds. Mesozoic Sub-Continental Lithospheric Thinning under Eastern Asia. London: Geological Society Special Publications. 280: 101-129

Guo P Y, Niu Y L, Ye L, Liu J J, Sun P, Cui H X, Zhang Y, Gao J P, Su L, Zhao J X, Feng Y X. 2014. Lithosphere thinning beneath west North China Craton: Evidence from geochemical and Sr-Nd-Hf isotope compositions of Jining basalts. Lithos, 202-203: 37-54

He L J. 2015. Thermal regime of the North China Craton: Implications for craton destruction. Earth-Sci Rev, 140: 14-26
Hu J M, Zhao Y, Liu X W, Xu G. 2010. Early Mesozoic deformations of the eastern Yanshan thrust belt, northern China. Int J Earth SciGeol Rundsch, 99: 785-800

Huang F, Xu J F, Liu Y S, Li J, Chen J L, Li X Y. 2017. Re-Os isotope evidence from Mesozoic and Cenozoic basalts for secular evolution of the mantle beneath the North China Craton. Contrib Mineral Petrol, 172: 28

Hughes H S R, McDonald I, Goodenough K M, Ciborowski T J R, Kerr A C, Davies J H F L, Selby D. 2014. Enriched lithospheric mantle keel below the Scottish margin of the North Atlantic Craton: Evidence from the Palaeoproterozoic Scourie Dyke Swarm and mantle xenoliths. Precambrian Res, 250: 97-126

Jiang Y H, Jin G D, Liao S Y, Zhou Q, Zhao P. 2010. Geochemical and Sr-Nd-Hf isotopic constraints on the origin of Late Triassic granitoids from the Qinling orogen, central China: Implications for a continental arc to continent-continent collision. Lithos, 117: 183-197

Kravchinsky V A, Cogne J P, Harbert W P, Kuzmin M I. 2002. Evolution of the Mongol-Okhotsk Ocean as constrained by new palaeomagnetic data from the Mongol-Okhotsk suture zone, Siberia. Geophys J Int, 148: 34-57

Kuritani T, Ohtani E, Kimura J I. 2011. Intensive hydration of the mantle transition zone beneath China caused by ancient slab stagnation. Nat Geosci, 4: 713-716

Kusky T M, Windley B F, Wang L, Wang Z, Li X, Zhu P. 2014. Flat slab subduction, trench suction, and craton destruction: Comparison of the North China, Wyoming, and Brazilian cratons. Tectonophysics, 630: 208-221

Lee C T A. 2006. Geochemical/petrologic constraints on the origin of cratonic mantle. In: Benn K, Mareschal J C, Condie L C, eds. Archean Geodynamics and Environments. Washington: Geophysical Monograph Series. 164: 89-114

Lee C T A, Luffi P, Chin E J. 2011. Building and destroying continental mantle. Annu Rev Earth Planet Sci, 39: 59-90

Li C M, Zhang C H, Cope T D, Lin Y. 2016. Out-of-sequence thrusting in polycyclic thrust belts: An example from the Mesozoic Yanshan belt, North China Craton. Tectonics, 35: 2082-2116

Li H Y, He B, Xu Y G, Huang X L. 2010. U-Pb and Hf isotope analyses of detrital zircons from Late Paleozoic sediments: Insights into interactions of the North China Craton with surrounding plates. J Asian Earth Sci, 39: 335-346

Li H Y, Xu Y G, Ryan J G, Huang X L, Ren Z Y, Guo H, Ning Z G. 2016. Olivine and melt inclusion chemical constraints on the source of intracontinental basalts from the eastern North China Craton: Discrimination of contributions from the subducted Pacific slab. Geochim Cosmochim Acta, 178: 1-19 
Li L, Santosh M, Li S R. 2015. The 'Jiaodong type' gold deposits: Characteristics, origin and prospecting. Ore Geol Rev, 65: 589-611

Li S G, Jagoutz E, Chen Y Z, Li Q L. 2000. Sm-Nd and Rb-Sr isotopic chronology and cooling history of ultrahigh pressure metamorphic rocks and their country rocks at Shuanghe in the Dabie Mountains, Central China. Geochim Cosmochim Acta, 64: 1077-1093

Li S G, Xiao Y L, Liou D L, Chen Y Z, Ge N J, Zhang Z Q, Sun S S, Cong B L, Zhang R Y, Hart S R. 1993. Collision of the North China and Yangtse Blocks and formation of coesite-bearing eclogites: Timing and processes. Chem Geol, 109: 89-111

Li S Z, Jahn B M, Zhao S J, Dai L M, Li X Y, Suo Y H, Guo L L, Wang Y M, Liu X C, Lan H Y, Zhou Z Z, Zheng Q L, Wang P C. 2017a. Triassic southeastward subduction of North China Block to South China Block: Insights from new geological, geophysical and geochemical data. Earth-Sci Rev, 166: 270-285

Li S Z, Zhao S J, Liu X, Cao H H, Yu S, Li X Y, Somerville I, Yu S Y, Suo Y H. 2017b. Closure of the Proto-Tethys Ocean and Early Paleozoic amalgamation of microcontinental blocks in East Asia. Earth-Sci Rev, doi: 10.1016/j.earscirev.2017.01.011

Li Y, Yang J S, Dilek Y, Zhang J, Pei X Z, Chen S Y, Xu X Z, Li J Y. 2015. Crustal architecture of the Shangdan suture zone in the early Paleozoic Qinling orogenic belt, China: Record of subduction initiation and backarc basin development. Gondwana Res, 27: 733744

Li S Q, Chen F K, Siebel W, Wu J D, Zhu X Y, Shan X L, Sun X M. 2012. Late Mesozoic tectonic evolution of the Songliao basin, NE China: Evidence from detrital zircon ages and $\mathrm{Sr}-\mathrm{Nd}$ isotopes. Gondwana Res, 22: 943-955

Lin W, Charles N, Chen Y, Chen K, Faure M, Wu L, Wang F, Li Q L, Wang J, Wang Q C. 2013a. Late Mesozoic compressional to extensional tectonics in the Yiwulüshan massif, NE China and their bearing on the Yinshan-Yanshan orogenic belt. Gondwana Res, 23: 78-94

Lin W, Faure M, Chen Y, Ji W, Wang F, Wu L, Charles N, Wang J, Wang Q C. 2013b. Late Mesozoic compressional to extensional tectonics in the Yiwulüshan massif, NE China and its bearing on the evolution of the Yinshan-Yanshan orogenic belt. Gondwana Res, 23: 54-77

Liu D Y, Nutman A P, Compston W, Wu J S, Shen Q H. 1992. Remnants of $\geq 3800$ Ma crust in the Chinese part of the Sino-Korean craton. Geology, 20: 339-342

Liu J G, Rudnick R L, Walker R J, Gao S, Wu F Y, Piccoli P M, Yuan H L, Xu W L, Xu Y G. 2011. Mapping lithospheric boundaries using Os isotopes of mantle xenoliths: An example from the North China Craton. Geochim Cosmochim Acta, 75: 3881-3902

Liu S F, Liu W C, Dai S W, Huang S J, Lu W Y. 2001. Thrusting and exhumation processes of a bounding mountain belt: Constraints from sediment provenance analysis of the Hefei basin. Acta Geol Sin-Engl Ed, 75: 144-150

Liu S F, Zhang G W. 2013. Mesozoic basin development and its indication of collisional orogeny in the Dabie orogen. Chin Sci Bull, 58: $827-852$

Liu X, Zhao D P, Li S Z, Wei W. 2017. Age of the subducting Pacific slab beneath East Asia and its geodynamic implications. Earth Planet Sci Lett, 464: 166-174

Liu Y S, Gao S, Kelemen P B, Xu W L. 2008. Recycled crust controls contrasting source compositions of Mesozoic and Cenozoic basalts in the North China Craton. Geochim Cosmochim Acta, 72: 23492376

Maruyama S, Isozaki Y, Kimura G, Terabayashi M. 1997. Paleogeographic maps of the Japanese Islands: Plate tectonic synthesis from $750 \mathrm{Ma}$ to the present. Isl Arc, 6: 121-142

Meng F X, Gao S, Niu Y L, Liu Y S, Wang X R. 2015. MesozoicCenozoic mantle evolution beneath the North China Craton: A new perspective from Hf-Nd isotopes of basalts. Gondwana Res, 27: $1574-1585$

Meng Q R. 2003. What drove late Mesozoic extension of the northern China-Mongolia tract? Tectonophysics, 369: 155-174

Meng Q R, Li S Y, Li R W. 2007. Mesozoic evolution of the Hefei basin in eastern China: Sedimentary response to deformations in the adjacent Dabieshan and along the Tanlu fault. Geol Soc Am Bull, 119: 897-916

Meng Q R, Wei H H, Wu G L, Duan L. 2014. Early Mesozoic tectonic settings of the northern North China craton. Tectonophysics, 611: $155-166$

Meng Q R, Zhang G W. 2000. Geologic framework and tectonic evolution of the Qinling orogen, central China. Tectonophysics, 323: 183-196

Metelkin D V, Vernikovsky V A, Kazansky A Y, Wingate M T D. 2010. Late Mesozoic tectonics of Central Asia based on paleomagnetic evidence. Gondwana Res, 18: 400-419

Niu Y L. 2014. Geological understanding of plate tectonics: Basic concepts, illustrations, examples and new perspectives. Global Tectonics Metal, 10: 23-47

Northrup C J, Royden L H, Burchfiel B C. 1995. Motion of the Pacific plate relative to Eurasia and its potential relation to Cenozoic extension along the eastern margin of Eurasia. Geology, 23: 719722

Park Y, Jung H. 2015. Deformation microstructures of olivine and pyroxene in mantle xenoliths in Shanwang, eastern China, near the convergent plate margin, and implications for seismic anisotropy. Int Geol Rev, 57: 629-649 
Pearson D G, Wittig N. 2008. Formation of Archaean continental lithosphere and its diamonds: The root of the problem. J Geol Soc, 165: 895-914

Qian S P, Ren Z Y, Richard W, Zhang L, Zhang Y H, Hong L B, Ding X L, Wu Y D. 2017. Petrogenesis of Early Cretaceous basaltic lavas from the North China Craton: Implications for cratonic destruction. J Geophys Res-Solid Earth, 485: 1900-1918

Ritts B D, Darby B J, Cope T. 2001. Early Jurassic extensional basin formation in the Daqing Shan segment of the Yinshan belt, northern North China Block, Inner Mongolia. Tectonophysics, 339: 239-258

Rudnick R L, Gao S, Ling W, Liu Y, McDonough W F. 2004. Petrology and geochemistry of spinel peridotite xenoliths from Hannuoba and Qixia, North China craton. Lithos, 77: 609-637

Russell J K, Porritt L A, Lavallée Y, Dingwell D B. 2012. Kimberlite ascent by assimilation-fuelled buoyancy. Nature, 481: 352-356

Safonova I Y, Santosh M. 2014. Corrigendum to "Accretionary complexes in the Asia-Pacific region: Tracing archives of Ocean Plate Stratigraphy and tracking mantle plumes" [Gondwana Res. 25 (2014) 126-158]. Gondwana Res, 26: 802

Seton M, Flament N, Whittaker J, Müller R D, Gurnis M, Bower D J. 2015. Ridge subduction sparked reorganization of the Pacific platemantle system 60-50 million years ago. Geophys Res Lett, 42: $1732-1740$

Shirey S B, Cartigny P, Frost D J, Keshav S, Nimis P, Nestola F, Pearson D G, Sobolev N V. 2013. Diamonds and the geology of mantle carbon. Rev Mineral Petrol, 75: 355-421

Sparks R S J. 2013. Kimberlite volcanism. Annu Rev Earth Planet Sci, 41: $497-528$

Su J B, Zhu W B, Chen J, Ge R, Zheng B, Min B. 2014. Cenozoic inversion of the East China Sea Shelf Basin: Implications for reconstructing Cenozoic tectonics of eastern China. Int Geol Rev, 56: $1541-1555$

Sun J, Liu C Z, Wu F Y, Yang Y H, Chu Z Y. 2012. Metasomatic origin of clinopyroxene in Archean mantle xenoliths from Hebi, North China Craton: Trace-element and Sr-isotope constraints. Chem Geol, 328: 123-136

Sun M D, Xu Y G, Wilde S A, Chen H L, Yang S F. 2015. The Permian Dongfanghong island-arc gabbro of the Wandashan Orogen, NE China: Implications for Paleo-Pacific subduction. Tectonophysics, 659: $122-136$

Sun W D, Ding X, Hu Y H, Li X H. 2007. The golden transformation of the Cretaceous plate subduction in the west Pacific. Earth Planet Sci Lett, 262: 533-542

Takashima R, Nishi H, Yoshida T. 2006. Late Jurassic-Early Cretaceous intra-arc sedimentation and volcanism linked to plate motion change in northern Japan. Geol Mag, 143: 753-770
Tang Y C, Obayashi M, Niu F L, Grand S P, Chen Y S J, Kawakatsu H, Tanaka S, Ning J Y, Ni J F. 2014. Changbaishan volcanism in northeast China linked to subduction-induced mantle upwelling. Nat Geosci, 7: 470-475

Tang Y J, Zhang H F, Ying J F, Su B X. 2013. Widespread refertilization of cratonic and circum-cratonic lithospheric mantle. Earth-Sci Rev, 118: 45-68

Tomurtogoo O, Windley B F, Kroner A, Badarch G, Liu D Y. 2005. Zircon age and occurrence of the Adaatsag ophiolite and Muron shear zone, central Mongolia: Constraints on the evolution of the Mongol-Okhotsk ocean, suture and orogen. J Geol Soc, 162: 125134

Wang C M, Deng J, Santosh M, Carranza E J M, Gong Q J, Guo C Y, Xia R, Lai X R. 2015. Timing, tectonic implications and genesis of gold mineralization in the Xincheng gold deposit, China: $\mathrm{C}-\mathrm{H}-\mathrm{O}$ isotopes, pyrite $\mathrm{Rb}-\mathrm{Sr}$ and zircon fission track thermochronometry. Ore Geol Rev, 65: 659-673

Wang C Y, Liu Y S, Min N, Zong K Q, Hu Z C, Gao S. 2016. PaleoAsian oceanic subduction-related modification of the lithospheric mantle under the North China Craton: Evidence from peridotite xenoliths in the Datong basalts. Lithos, 261: 109-127

Wang F, Xu W L, Xu Y G, Gao F H, Ge W C. 2015. Late Triassic bimodal igneous rocks in eastern Heilongjiang Province, NE China: Implications for the initiation of subduction of the Paleo-Pacific Plate beneath Eurasia. J Asian Earth Sci, 97: 406-423

Wang F, Xu Y G, Xu W L, Yang L, Wu W, Sun C Y. 2017. Early Jurassic calc-alkaline magmatism in northeast China: Magmatic response to subduction of the Paleo-Pacific Plate beneath the Eurasian continent. J Asian Earth Sci, 143: 249-268

Wang Q C, Cong B L, Ma L. 1997. Structural coupling of the Dabie Orogen with Hefei Basin. Chin Sci Bull, 42: 1566-1572

Wang T, Guo L, Zheng Y D, Donskaya T, Gladkochub D, Zeng L S, Li J B, Wang Y B, Mazukabzov A. 2012. Timing and processes of late Mesozoic mid-lower-crustal extension in continental NE Asia and implications for the tectonic setting of the destruction of the North China Craton: Mainly constrained by zircon U-Pb ages from metamorphic core complexes. Lithos, 154: 315-345

Wang T, Zheng Y D, Zhang J J, Zeng L S, Donskaya T, Guo L, Li J B. 2011. Pattern and kinematic polarity of late Mesozoic extension in continental NE Asia: Perspectives from metamorphic core complexes. Tectonics, 30: TC6007

Wang Z Z, Han B F, Feng L X, Liu B, Zheng B, Kong L J. 2016. Tectonic attribution of the Langshan area in western Inner Mongolia and implications for the Neoarchean-Paleoproterozoic evolution of the Western North China Craton: Evidence from LA-ICP-MS zircon $\mathrm{U}-\mathrm{Pb}$ dating of the Langshan basement. Lithos, 261: 278-295 
Windley B F, Alexeiev D, Xiao W, Kroner A, Badarch G. 2007. Tectonic models for accretion of the Central Asian Orogenic Belt. J Geol Soc, 164: 31-47

Windley B F, Maruyama S, Xiao W J. 2010. Delamination/thinning of sub-continental lithospheric mantle under Eastern China: The role of water and multiple subduction. Am J Sci, 310: 1250-1293

Wong W H. 1927. Crustal movements and igneous activities in Eastern China since Mesozoic Time. Bull Geol Soc China, 6: 9-37

Wu D, Liu Y S, Chen C F, Xu R, Ducea M N, Hu Z C, Zong K Q. 2017. In-situ trace element and $\mathrm{Sr}$ isotopic compositions of mantle xenoliths constrain two-stage metasomatism beneath the northern North China Craton. Lithos, 288-289: 338-351

Wu F Y, Walker R J, Ren X W, Dun D Y, Zhou X H. 2003. Osmium isotopic constraints on the age of lithospheric mantle beneath northeastern China. Chem Geol, 196: 107-129

Wu Y B, Hanchar J M, Gao S, Sylvester P J, Tubrett M, Qiu H N, Wijbrans J R, Brouwer F M, Yang S H, Yang Q J, Liu Y S, Yuan H. 2009. Age and nature of eclogites in the Huwan shear zone, and the multi-stage evolution of the Qinling-Dabie-Sulu orogen, central China. Earth Planet Sci Lett, 277: 345-354

Wu Y B, Zheng Y F. 2013. Tectonic evolution of a composite collision orogen: An overview on the Qinling-Tongbai-Hong'an-Dabie-Sulu orogenic belt in central China. Gondwana Res, 23: 1402-1428

Xiao W J, Windley B F, Sun S, Li J L, Huang B C, Han C M, Yuan C, Sun M, Chen H L. 2015. A tale of amalgamation of three PermoTriassic Collage Systems in Central Asia: Oroclines, sutures, and terminal accretion. Annu Rev Earth Planet Sci, 43: 477-507

Xu M, Li Y L, Hou H S, Wang C S, Gao R, Wang H Y, Han Z P, Zhou A. 2017. Structural characteristics of the Yilan-Yitong and DunhuaMishan faults as northern extensions of the Tancheng-Lujiang Fault Zone: New deep seismic reflection results. Tectonophysics, 706707: $35-45$

Xu R, Liu Y S, Tong X R, Hu Z C, Zong K Q, Gao S. 2013. In-situ trace elements and $\mathrm{Li}$ and $\mathrm{Sr}$ isotopes in peridotite xenoliths from Kuandian, North China Craton: Insights into Pacific slab subduction-related mantle modification. Chem Geol, 354: 107-123

Xu X S, O'Reilly S Y, Griffin W L, Zhou X M, Huang X L. 2013. The nature of the Cenozoic lithosphere at Nushan, eastern China. In: Flower M F J, Chung S L, Lo C H, Lee T Y, eds. Mantle Dynamics and Plate Internationals in East Asia. Washington: American Geophysical Union. 167-195

Xu Y G. 2001. Thermo-tectonic destruction of the archaean lithospheric keel beneath the sino-korean craton in china: Evidence, timing and mechanism. Phys Chem Earth Part A-Solid Earth Geodesy, 26: 747 757

Xu Y G, Blusztajn J, Ma J L, Hart S R. 2006. In searching for old lithospheric relict beneath North China craton: Sr-Nd-Os isotopic composition of peridotite xenoliths from Yangyuan. Geochim Cosmochim Acta, 70: A714-A714

Xu Y G, Blusztajn J, Ma J L, Suzuki K, Liu J F, Hart S R. 2008. Late Archean to Early Proterozoic lithospheric mantle beneath the western North China craton: Sr-Nd-Os isotopes of peridotite xenoliths from Yangyuan and Fansi. Lithos, 102: 25-42

Xu Y G, Menzies M A, Thirlwall M F, Huang X L, Liu Y, Chen X M. 2003. "Reactive" harzburgites from Huinan, NE China: Products of the lithosphere-asthenosphere interaction during lithospheric thinning? Geochim Cosmochim Acta, 67: 487-505

Yang J H, O'Reilly S, Walker R J, Griffin W, Wu F Y, Zhang M, Pearson N. 2010. Diachronous decratonization of the Sino-Korean craton: Geochemistry of mantle xenoliths from North Korea. Geology, 38: 799-802

Yang T N, Peng Y, Leech M L, Lin H Y. 2011. Fold patterns indicating Triassic constrictional deformation on the Liaodong peninsula, eastern China, and tectonic implications. J Asian Earth Sci, 40: 7283

Yang W, Li S G. 2008. Geochronology and geochemistry of the Mesozoic volcanic rocks in Western Liaoning: Implications for lithospheric thinning of the North China Craton. Lithos, 102: 88117

Yang Z Y, Ma X H, Huang B C, Sun Z M, Zhou Y X. 1998. Apparent polar wander path and tectonic movement of the North China Block in Phanerozoic. Sci China Ser D-Earth Sci, 41: 51-65

Yin A, Nie S Y. 1996. A Phanerozoic palinspasticre construction of China and its neighboring regions. In: Yin A, Harrison T M, eds. The Tectonic Evolution of Asia. Cambridge: Cambridge University Press. $442-485$

Zhai M G, Santosh M. 2011. The early Precambrian odyssey of the North China Craton: A synoptic overview. Gondwana Res, 20: 6-25

Zhang H F, Goldstein S L, Zhou X H, Sun M, Zheng J P, Cai Y. 2008. Evolution of subcontinental lithospheric mantle beneath eastern China: Re-Os isotopic evidence from mantle xenoliths in Paleozoic kimberlites and Mesozoic basalts. Contrib Mineral Petrol, 155: 271293

Zhang H F, Sun M, Zhou X H, Fan W M, Zhai M G, Yin J F. 2002. Mesozoic lithosphere destruction beneath the North China Craton: Evidence from major-, trace-element and $\mathrm{Sr}-\mathrm{Nd}-\mathrm{Pb}$ isotope studies of Fangcheng basalts. Contrib Mineral Petrol, 144: 241-254

Zhang H F, Sun M, Zhou M F, Fan W M, Zhou X H, Zhai M G. 2004. Highly heterogeneous Late Mesozoic lithospheric mantle beneath the North China Craton: Evidence from $\mathrm{Sr}-\mathrm{Nd}-\mathrm{Pb}$ isotopic systematics of mafic igneous rocks. Geol Mag, 141: 55-62

Zhang S H, Zhao Y, Davis G A, Ye H, Wu F. 2014. Temporal and 
spatial variations of Mesozoic magmatism and deformation in the North China Craton: Implications for lithospheric thinning and decratonization. Earth-Sci Rev, 131: 49-87

Zhang S H, Zhao Y, Song B, Hu J M, Liu S W, Yang Y H, Chen F K, Liu X M, Liu J. 2006. Contrasting Late Carboniferous and Late Permian-Middle Triassic intrusive suites from the northern margin of the North China craton: Geochronology, petrogenesis, and tectonic implications. Geol Soc Am Bull, 121: 181-200

Zhang S H, Zhao Y, Song B, Yang Z Y, Hu J M, Wu H. 2007. Carboniferous granitic plutons from the northern margin of the North China block: Implications for a late Palaeozoic active continental margin. J Geol Soc, 164: 451-463

Zhang S H, Zhao Y, Ye H, Hou K J, Li C F. 2012. Early Mesozoic alkaline complexes in the northern North China Craton: Implications for cratonic lithospheric destruction. Lithos, 155: 1-18

Zhang W H, Zhang H F, Sun Y L, Fan W M, Han B F, Tang Y J. 2015. Platinum-group element geochemistry of Cenozoic basalts from the North China Craton: Implications for mantle heterogeneity. Sci China Earth Sci, 58: 881-895

Zhao D P, Tian Y, Lei J S, Liu L, Zheng S H. 2009. Seismic image and origin of the Changbai intraplate volcano in East Asia: Role of big mantle wedge above the stagnant Pacific slab. Phys Earth Planet Inter, 173: 197-206

Zhao G C, Sun M, Wilde S A, Sheng S H. 2005. Late Archean to Paleoproterozoic evolution of the North China Craton: Key issues revisited. Precambrian Res, 136: 177-202

Zhao G C, Wilde S A, Li S Z, Sun M, Grant M L, Li X P. 2007. U-Pb zircon age constraints on the Dongwanzi ultramafic-mafic body, North China, confirm it is not an Archean ophiolite. Earth Planet Sci Lett, 255: 85-93

Zhao P, Chen Y, Xu B, Faure M, Shi G, Choulet F. 2013. Did the PaleoAsian Ocean between North China Block and Mongolia Block exist during the late Paleozoic? First paleomagnetic evidence from central-eastern Inner Mongolia, China. J Geophys Res-Solid Earth, 118: 1873-1894

Zheng J P, Griffin W L, O'Reilly S Y, Hu B Q, Zhang M, Tang H Y, Su Y P, Zhang Z H, Pearson N, Wang F Z, Lu F X. 2008a. Continental collision and accretion recorded in the deep lithosphere of central China. Earth Planet Sci Lett, 269: 497-507

Zheng J P, Griffin W L, O'Reilly S Y, Lu F X, Wang C Y, Zhang M, Wang F Z, Li H M. 2004a. 3.6 Ga lower crust in central China: New evidence on the assembly of the North China craton. Geology, 32: 229-232

Zheng J P, Griffin W L, O'Reilly S Y, Yang J S, Li T Y, Zhang M, Zhang R Y, Liou J G. 2006b. Mineral chemistry of peridotites from Paleozoic, Mesozoic and Cenozoic Lithosphere: Constraints on mantle evolution beneath Eastern China. J Petrol, 47: 2233-2256

Zheng J P, Griffin W L, O'Reilly S Y, Yang J S, Zhang R Y. 2006c. A refractory mantle protolith in younger continental crust, east-central China: Age and composition of zircon in the Sulu ultrahigh-pressure peridotite. Geology, 34: 705-708

Zheng J P, Griffin W L, O'Reilly S Y, Yu C M, Zhang H F, Pearson N, Zhang M. 2007. Mechanism and timing of lithospheric modification and replacement beneath the eastern North China Craton: Peridotitic xenoliths from the $100 \mathrm{Ma}$ Fuxin basalts and a regional synthesis. Geochim Cosmochim Acta, 71: 5203-5225

Zheng J P, Griffin W L, O'Reilly S Y, Zhang M, Pearson N. 2006a. Zircons in mantle xenoliths record the Triassic Yangtze-North China continental collision. Earth Planet Sci Lett, 247: 130-142

Zheng J P, Lee C T A, Lu J G, Zhao J H, Wu Y B, Xia B, Li X Y, Zhang J F, Liu Y S. 2015. Refertilization-driven destabilization of subcontinental mantle and the importance of initial lithospheric thickness for the fate of continents. Earth Planet Sci Lett, 409: 225231

Zheng J P, O'Reilly S Y, Griffin W L, Lu F X, Zhang M, Pearson N J. 2001. Relict refractory mantle beneath the eastern North China block: Significance for lithosphere evolution. Lithos, 57: 43-66

Zheng J P, O’Reilly S Y, Griffin W L, Lu F X, Zhang M. 1998. Nature and evolution of Cenozoic lithospheric mantle beneath Shandong Peninsula, Sino-Korean Craton, Eastern China. Int Geol Rev, 40: 471-499

Zheng J P, O’Reilly S Y, Griffin W L, Zhang M, Lu F X, Liu G L. 2004b. Nature and evolution of Mesozoic-Cenozoic lithospheric mantle beneath the Cathaysia block, SE China. Lithos, 74: 41-65

Zheng J P, Sun M, Griffin W L, Zhou M F, Zhao G C, Robinson P, Tang H Y, Zhang Z H. 2008b. Age and geochemistry of contrasting peridotite types in the Dabie UHP belt, eastern China: Petrogenetic and geodynamic implications. Chem Geol, 247: 282-304

Zheng J P, Tang H Y, Xiong Q, Griffin W L, O'Reilly S Y, Pearson N, Zhao J H, Wu Y B, Zhang J F, Liu Y S. 2014. Linking continental deep subduction with destruction of a cratonic margin: Strongly reworked North China SCLM intruded in the Triassic Sulu UHP belt. Contrib Mineral Petrol, 168: 1-21

Zheng Y F, Fu B, Gong B, Li L. 2003. Stable isotope geochemistry of ultrahigh pressure metamorphic rocks from the Dabie-Sulu orogen in China: Implications for geodynamics and fluid regime. Earth-Sci Rev, 62: 105-161

Zheng Y F, Zhou J B, Wu Y B, Xie Z. 2005. Low-grade metamorphic rocks in the Dabie-Sulu Orogenic Belt: A passive-margin accretionary wedge deformed during continent subduction. Int Geol Rev, 47: 851-871

Zheng Y, Zhang Q, Wang Y, Liu R, Wang S G, Zuo G, Wang S Z, 
Lkaasuren B, Badarch G, Badamgarav Z. 1996. Great Jurassic thrust sheets in Beishan (North Mountains) - Gobi areas of China and southern Mongolia. J Struct Geol, 18: 1111-1126

Zhu G, Chen Y, Jiang D Z, Lin S Z. 2015. Rapid change from compression to extension in the North China Craton during the Early Cretaceous: Evidence from the Yunmengshan metamorphic core complex. Tectonophysics, 656: 91-110

Zhu G, Niu M L, Xie C L, Wang Y S. 2010. Sinistral to normal faulting along the Tan-Lu Fault Zone: Evidence for geodynamic switching of the East China continental margin. J Geol, 118: 277-293

Zhu G, Wang Y S, Liu G S, Niu M L, Xie C L, Li C C. $2005 .{ }^{40} \mathrm{Ar} /{ }^{39} \mathrm{Ar}$ dating of strike-slip motion on the Tan-Lu fault zone, East China. J Struct Geol, 27: 1379-1398

Zou D Y, Zhang H F, Hu Z C, Santosh M. 2016. Complex metasomatism of lithospheric mantle by asthenosphere-derived melts: Evidence from peridotite xenoliths in Weichang at the northern margin of the North China Craton. Lithos, 264: 210-223

(责任编委: 郑永飞) 